\title{
The Burrup Peninsula and Dampier Archipelago, Western Australia: an introduction to the history of its discovery and study, marine habitats and their flora and fauna
}

\author{
Diana S. Jones \\ Department of Aquatic Zoology (Crustacea), Western Australian Museum, \\ Francis Street, Perth, Western Australia 6000, Australia \\ email: diana.jones@museum.wa.gov.au
}

\section{INTRODUCTION}

The Dampier Archipelago lies between latitudes $20^{\circ} 20^{\prime} \mathrm{S}-20^{\circ} 45^{\prime} \mathrm{S}$ and longitudes $116^{\circ} 24^{\prime} \mathrm{S}-117^{\circ} 05^{\prime} \mathrm{E}$ on the Pilbara coast in northwestern Australia, with the towns of Dampier and Karratha as its focus. The archipelago is situated at the eastern end of an extensive chain of small coastal islands between Exmouth and Dampier and is one of the major physical features of the Pilbara coast (Figures 1 and 2). Western Australia's mineral resources sector is flourishing and much of the state's investment potential lies in the iron ore and gas and oil-rich Pilbara region, an area of distinctive climate, geology, land forms, soils, vegetation and biota.

The environment and flora and fauna, both marine and terrestrial, of the Dampier Archipelago have considerable regional significance and are subject to increasing human impacts. This is an introduction to the archipelago, its climate, geology and landform and the marine environments that surround it. First, however, the history of its earliest occupation, discovery by western explorers and the modern economic forces that are driving the development of the archipelago are described.

\section{Historical Context}

There is abundant evidence of previous occupation of the islands of the Dampier Archipelago by Aboriginal people and their ancestors, in the form of shell middens, stone "factory" sites and rock art. The latter is of worldwide significance (Vinnicombe, 2002). Aboriginal people utilized the area long before rising sea levels isolated coastal plains and hills to create the archipelago, approximately 7,000 years ago (Lorblanchet, 1989; Veth et al., 1993). Today, local Aboriginal communities continue to hunt and fish in the region.

Dutch navigators knew of the group of islands now known as the Dampier Archipelago. A chart drawn in 1628 for the Dutch East India Company shows the archipelago, as well as Barrow and the Montebello Islands. It was, however, the
Englishman William Dampier who made the first recorded European visit to the archipelago in 1688 (Dampier, 1697). Aboard Captain Swan's Cygnet, he spent nine weeks on the northwestern coast of Western Australia. Returning in 1699 aboard the Roebuck, the ship anchored off Enderby Island on 31 August and on 1 September, Dampier landed on an island which he named "Rosemary" due to the presence of a plant (presently known as Eurybia dampieri but awaiting formal publication in Olearia) that reminded him of a herb of that name (George, 1999).

The French navigator St Allouarn noted "Rosemary Island" while sailing from North West Cape to Timor in 1722, but made no landing (Henn, 1934). In 1801, Captain Nicolas Baudin's expedition on the Géographe named the group of islands Dampier's Archipelago (Péron et al., 1807-1816). A number of islands in the archipelago were also named after renowned French scientists and academics by members of Baudin's expedition. Malus Island was named after Étienne Louis Malus (1775-1812), a physicist and academician wellknown for his study of optics; Legendre after Adrien Marie Legendre (1752-1834), mathematician, geometrist and academician; Haûy after René Just Haûy (1743-1822), a celebrated mineralogist, and Delambre after Jean Baptiste Joseph Delambre (1749-1822), a distinguished astronomer and mathematician.

To the west of the Dampier Archipelago, Regnard Bay and the Regnard Islands near Cape Preston were also named by Baudin (after Jean François Regnard, a noted poet) and to the east of the archipelago, Depuch Island and the Forestier Archipelago, after Louis Depuch, mineralogist on the Géographe and François Louis, Baron Forestier (1776-1814), a distinguished general who fought with Napoléon, respectively.

Due to an error by Baudin's navigator, Louis de Freycinet, Dampier's name of "Rosemary" was assigned to an island a few kilometers to the northwest of Malus Island and was thus thought to be one of the outer islands of the Dampier 


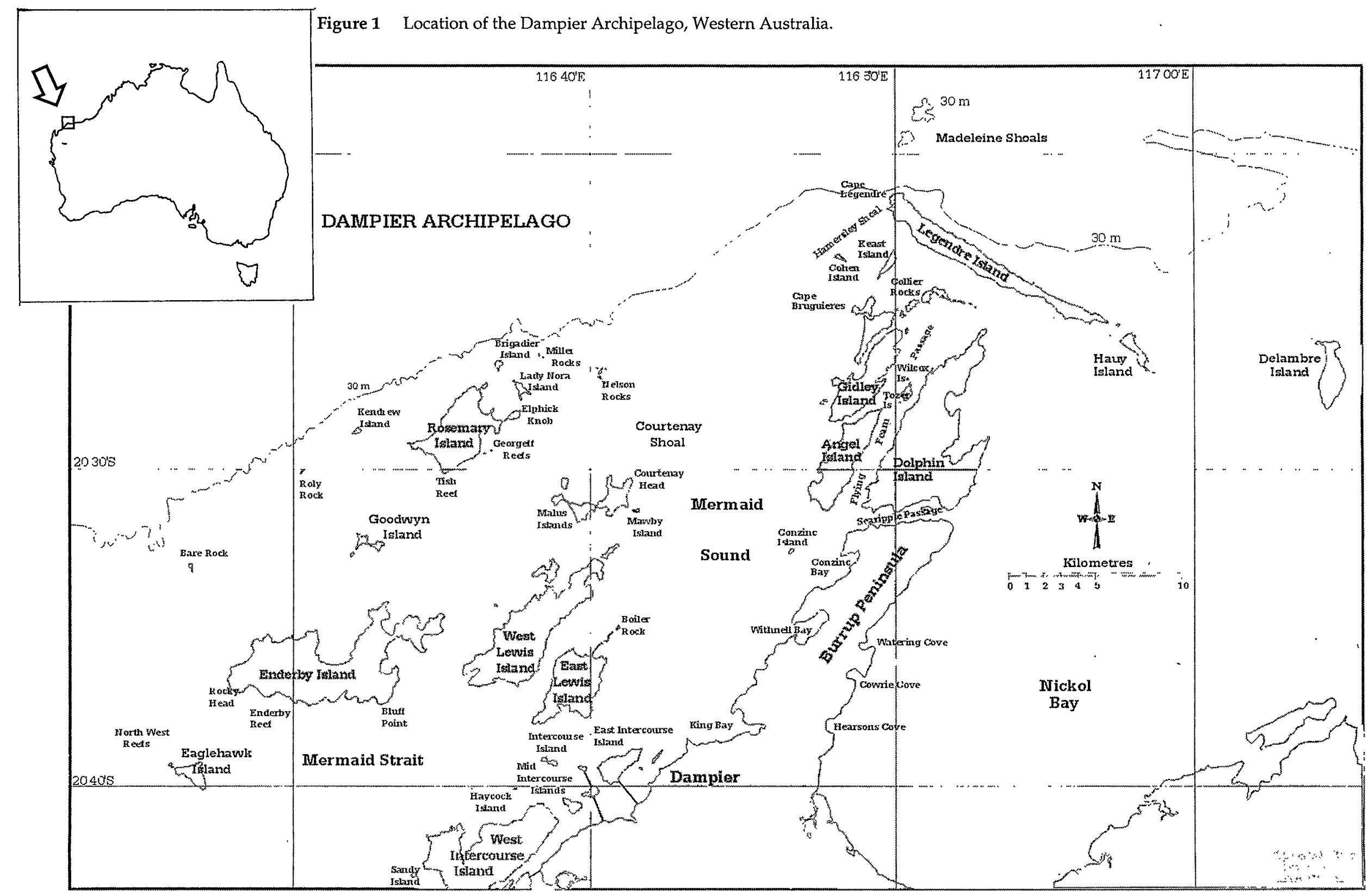

Figure 2 Detail of the Dampier Archipelago and Burrup Peninsula. 
Archipelago. However, research has shown that Dampier's "Rosemary" is almost certainly East Lewis Island (King, 1827; Tuckfield, 1955; George, 1971, 1999; Marchant, 1998).

In 1818, Lieutenant Philip Parker King on the Mermaid made a more detailed survey of the Dampier Archipelago, naming Enderby, Gidley, the Lewis and the Intercourse Islands, as well as Nickol Bay on its eastern flank. Mention was made by Lieutenant Helpman in 1851 of "numerous fresh native foot marks on the beach" and three graves (believed to be of early whalers) on Enderby Island.

The first Europeans to explore the inland Pilbara region arrived on the Dolphin, under the leadership of Surveyor F. T. Gregory in 1861. They landed at Hearson Cove on the eastern shore of the Burrup Peninsula on 11 May 1861 and named Dolphin Island after their ship. The name given to the Hamersley district is that originally applied to the most noticeable feature of the region, the Hamersley Range, by Gregory on 6 June 1861. This was named in honor of Edward Hamersley, who at the time was a member of the Western Australian Legislative Assembly and a sponsor of the expedition.

\section{Contemporary Context}

Modern day Dampier (population approximately $1,800)$ is situated on what was once an island separated from the mainland by a large area of mangroves and a high tidal salt flat. A causeway now joins the town to the mainland. Mistaken, East Mid Intercourse and East Intercourse Islands have also been joined by a causeway to the mainland. Dampier is a company town operated by Hamersley Iron Pty. Ltd. and is the port for the inland iron-ore mining operations at Tom Price and Paraburdoo. Port facilities were constructed in 1966. Currently, Dampier is Australia's largest tonnage port (75 million tonnes per annum) and is responsible for $20 \%$ (A $\$ 5-6$ billion dollars) of the state's annual export revenue. It is also the gateway to the North West Shelf oil and gas industry. Being a natural deep-water port, the facilities offer relatively easy access to industry and their terminals on the Burrup Peninsula.

Today, the nearby town of Karratha (population presently approximately 11,300) on the southern shore of Nickol Bay is the Shire of Roebourne's administrative centre and the regional focus for many businesses and government departments. The name, derived from an Aboriginal name for the area meaning "good country" or "soft earth", was adopted in the 1860's by the two original owners of the Karratha Station, Dr Baynton and Harry Whittal Venn. The land on which the town is built was resumed from the pastoral station in 1968. The township was founded because of the continued expansion of the Hamersley Iron operation, the lack of suitable land for expansion in Dampier and the start of the nearby Dampier Salt Ltd. project. The town has grown to become a thriving business centre and, through the development of the immense offshore gas reserves by the Woodside Energy Ltd. North West Shelf Gas Project, the growth of Karratha has gained even more momentum.

\section{Natural Resources}

The Dampier Archipelago and adjacent waters have been fished sporadically on a commercial basis since the late $1800^{\prime}$ s for pearl shell, turtles, tuna, and whales. In 1861, F. T. Gregory noted that the pearl shell, Pteria penguin (Röding, 1798), was abundant in the waters of the Dampier Archipelago. A pearling fleet became established soon after at Cossack and Flying Foam Passage (between Gidley and Angel Islands to the west and Dolphin Island to the east) and, between 1870 and 1900, the region was the major commercial pearling area in the northwest. By the late 1860 's, ten pearling luggers operated from Nickol Bay. The 1920's, however, saw a decline in pearling in the northwest and the small Nickol Bay settlement was abandoned. From 1870-1872 a whaling station was established on Malus Island to process Humpback whales, Megaptera novaeangliae (Borowski, 1781), taken by long boats operating around the Dampier Archipelago (MacIlroy, 1979). This commercial venture was started by American whalers as early as 1840. Later, the islands were used for pastoral purposes as well as providing shelter and campsites for commercial fishermen operating from Onslow and Point Sampson. Turtles and their eggs were taken commercially around the Dampier Archipelago during this period and a turtle meat canning company operated at Cossack (Pilbara 21, 1992).

Currently, the Pilbara Fish Trawl and the Pilbara Trap Fisheries provide the majority of the state's demersal fin fish (Penn, 2002), targeting nor-west snappers (Lethrinidae), sea perches (Lutjanidae), threadfin breams (Nemipteridae) and groupers (Serranidae). One of Western Australia's smaller prawn trawl fisheries, for the Banana prawn, Penaeus merguiensis de Man, 1888, is based in Nickol Bay and a cultured pearl industry using Pinctada maxima (Jameson, 1901) flourishes in the area.

\section{Mineral Resources}

The Burrup Peninsula is a key coastal development node and is among the most strategic pieces of industrial land in Australia. Salt, iron ore and liquefied natural gas (LNG) shipping facilities, salt evaporators and associated plant centered on Mermaid Sound and the lower Burrup Peninsula are of major economic importance. In addition, the area is rich in offshore oil and gas. For the past 30 
40 years, oil and gas exploration and production activities have been conducted in the region, including the area around the Dampier Archipelago.

Further expansions are planned for the Dampier area in terms of both the development of downstream iron ore projects and the possible expansion of the natural gas and petrochemical industries. More than \$A6 billion worth of petrochemical enterprises (methanol, ammonia and gas-to-liquid products) using natural gas from the North West Shelf are currently being planned for the Burrup Peninsula and can be expected to commence operation within the next five years. There are also potentially large quantities of minerals and untapped natural gas resources waiting to be developed. Additional shipping channels and berths will need to be provided for these projects. Major work is also proposed for the port of Dampier, with the Western Australian Government pledging (in 2002) A $\$ 13$ million for dredging.

\section{Cultural, Recreational and Tourism Values}

In addition to its commercial value, the Dampier Archipelago has high cultural, recreational and tourism values. Together, the Burrup Peninsula and the Dampier Archipelago form one of the main physical features of the Pilbara coast. They are popular recreational and tourist areas, whose attractions include pristine, white sandy beaches, fringing coral reefs, Aboriginal rock art, spectacular snorkelling and diving, as well as some of the best recreational and sports fishing in Western Australia. The area exhibits exceptional natural beauty, abundant natural diversity and a pleasant, warm climate, as well as close proximity to areas of significant Aboriginal and European cultural value.

There is extensive recreational use of the waters of the Dampier Archipelago. Line fishing, diving and shell-collecting are popular activities enjoyed by local people from the towns of Dampier, Karratha and the nearby townships of Wickham and Roebourne. Most households own a small boat capable of reaching the outer islands and charter boats additionally cater for tourist needs. Along the Pilbara coast, the islands of the Dampier Archipelago have the greatest potential for tourism.

The Dampier Archipelago Islands Management Plan (2000) contained a recommendation that the waters of the archipelago should be considered for designation as a marine park. In 1994, the Marine Parks and Reserves Working Group Report recommended that the waters of the Dampier Archipelago, excluding the inner portion of Mermaid Sound and the functional area of the Port of Dampier, should be considered as a reserve. Currently, the region from Cape Preston to Nickol
Bay has been proposed as a marine conservation reserve (Osborne et al., 2002).

The Burrup Peninsula holds special significance for local Aboriginal people and is environmentally sensitive. At present, there are four Native Title claims lodged with the National Native Title Tribunal by Aboriginal people who claim traditional associations with the local land and sea of some or all of this West Pilbara area. All applications lay claim to coastal waters sampled during the Western Australian Museum/Woodside Energy Ltd. partnership to explore the marine biodiversity of the Dampier Archipelago. One claim has minor and three have major coverage of this area. The claims are currently awaiting mediation in the Federal Court (Osborne et al., 2002).

\section{THE PHYSICAL ENVIRONMENT}

\section{Geology}

Several publications have described the regional geology, including that of the Dampier Archipelago, in varying amounts of detail, e.g. Kriewaldt, 1964; Ryan, 1966; Biggs, 1979, 1980; Geological Survey of Western Australian, 1980; Semeniuk et al., 1982; Hickman, 1983; Kojan, 1994; Morris, 1995; Carr and Livesey, 1996.

Precambrian early Archaean (older than $2800 \mathrm{Ma}$ ) granite and gneiss outcrop in the Dampier-Karratha area on the western margin of the Pilbara Craton, for example on Enderby, Tozer and Dolphin Islands and on the mainland near Karratha (Hickman, 1983). The youngest igneous rocks in the area are long, narrow, dolerite dykes which cut all other Precambrian rocks.

Precambrian late Archaean (younger than 2800 Ma) rocks unconformably overlie the early Archaean rocks and give rise to the rugged topography of the Burrup Peninsula and the major islands. Many of the islands of the archipelago comprise basalt and sandstone of the Proterozoic Fortescue Group. Igneous rocks of the Gidley Granophyre and associated gabbro and dolerite intrude the Fortescue formations, the granophyre forming the major part of the Burrup Peninsula. It also forms significant portions of Dolphin, Angel, Gidley, East Lewis and Enderby Islands. A probable age range for these intrusions is 2700-2400 Ma. Dolerite sills intrude the Fortescue Group formations on Enderby, East Lewis and Rosemary Islands (Kriewaldt, 1964; Biggs, 1979, 1980; Geological Survey of Western Australian, 1980; Kojan, 1994).

Quaternary deposits of clay, gravel, calcrete, aeolian calcarenites, mud and silt partially mantle the Precambrian rocks of the Dampier Archipelago and adjacent mainland. The calcarenites of the flatter outer islets and islands in the north of the 
archipelago, e.g. Legendre, Haüy and Delambre Islands and Collier Rocks, are remnants of a Pleistocene dune barrier feature and have been correlated with the Tamala Limestone of the Perth and Carnarvon Basins and the Bossut Formation of the Canning Basin (Kojan, 1994). Most of the submerged area within the limits of the Dampier Archipelago (Mermaid Sound) is formed of 'limestone'. In the more southerly, inshore part of the archipelago, the 'limestone' passes laterally into clay; further offshore it generally overlies the Precambrian basement. Gravel, sand, silt and clay deposits of Pleistocene to Holocene age cover extensive nearshore areas of the mainland. They represent a complex of fluctuating shoreline and alluvial sheet-flood deposits, locally calcreted. Offshore, areas of seafloor within the archipelago are formed of similar gravels and limestone conglomerates (Kojan, 1994).

Limestone deposits occur widely on the islands of the Archipelago, e.g. Enderby, Rosemary, Eaglehawk and Delambre Islands, and on the adjacent mainland, as at Hearson Cove and Cleaverville, the latter two being quarry sites (Ryan, 1966; Kojan, 1994). The sands, of bioclastic carbonate and subordinate quartz, have accumulated over the last 6,000 years in favorable, inshore areas since the Middle Holocene stabilization of sea level (Playford, 1988). More sheltered, low energy embayments feature silty to muddy substrata, usually occupied by mangroves; these however also occur on sandy and rocky shores of both the archipelago and the adjacent Burrup Peninsula (Semeniuk and Wurm, 1987).

A saline depression, subject to partial tidal incursion from the west, separates the present Burrup Peninsula from the mainland proper. Fossil deposits indicate that the depression was the site of a shallow, marine channel during the trangressive peak of the Middle Holocene, apparently contemporaneous with the shelly Herschell Limestone of Rottnest Island (Playford, 1988).

\section{Landform}

With a gross area of about $1000 \mathrm{~km}^{2}$, the contemporary Dampier Archipelago represents a mostly submerged terrain of the inner continental shelf, essentially similar to that of the present hinterland. Approximately 6,000-8,000 years ago, the position of the coastline in this area encompassed the periphery of what is now the archipelago. Rising sea levels, caused by a general global warming and partial melting of polar ice following the Last Glacial Maximum of the Late Pleistocene, submerged the continental shelf, leaving areas of high relief exposed as islands to form the present Dampier Archipelago (Merrilees, 1979; Semeniuk et al., 1982). The archipelago is a ria coast (Semeniuk et al., 1982; Marine Parks and
Reserves Selection Working Group, 1994). Today, a steep slope to the $30 \mathrm{~m}$ depth contour around the archipelago, close to the outer shores of the outer islands, represents the position of a previous shoreline and sharply demarcates Nickol Bay and the Dampier Archipelago from the oceanic waters of the inner part of the North West Shelf.

Forty-two islands, islets and rocks with associated reefs and shoals comprise in aggregate about 15\% of the surface area of the archipelago (Figure 2). These rise from the submerged floor of Mermaid Sound, an undulating sub-littoral plain comprising $60 \%$ of the total area of the Dampier Archipelago, at depths of from 5 to $20 \mathrm{~m}$ (Semeniuk et al., 1982; Semeniuk, 1986).

A number of large islands occur in the Dampier Archipelago (for example Enderby, Rosemary, West Lewis, East Lewis, Angel, Gidley, Dolphin, Legendre and Delambre), the largest being Enderby, with an area of approximately 3,290 hectares, followed by Dolphin (approximately 3,203 hectares) which is also the highest, rising to $120 \mathrm{~m}$ above sea level. Between 1-20 km from the mainland there are numerous smaller islands and islets, the smallest being one hectare or less, e.g. Nelson and Millers Rocks and Tozer and Egret Islands. Eaglehawk, Goodwyn, Malus, Keast, Haûy and Delambre Islands are some distance offshore, with West Intercourse, West Mid Intercourse, East Mid Intercourse, East Intercourse, Mistaken and Tidepole Islands closer inshore. At low tide, the large nearshore West Intercourse Island is joined to the mainland. In the present study, Eaglehawk is regarded as the westernmost island of the archipelago, and Delambre the most eastern (Figure 2).

The small outer islands, such as Millers and Nelson Rocks, and the larger islands in the north of the archipelago, such as Kendrew, Brigadier, Legendre, Haûy and Delambre, are composed of limestone of Pleistocene or Holocene origin, with fringing intertidal platforms and coral reefs (Wilson and Marsh, 1974). Beaches on these low, flat islands are often backed by a low, undercut sea cliff in consolidated dune limestone, rather than a sand dune. These islands tend to be aligned around the seaward margin of the archipelago and represent consolidated limestone ridges which are remnants of the coastal dune system of an earlier time of lower than present sea level.

The inner islands and the Burrup Peninsula consist of a complex of Archaean and Proterozoic, mostly crystalline, igneous rocks. Late Pleistocene sandy limestones occur locally on the igneous base, mainly at depth but less frequently at present sea level. Many of the present day coral reefs of the Dampier Archipelago consist of a living veneer of corals on relic Pleistocene reefs. Varying thicknesses of sand/gravel and mud deposits overlie the rocks, 
with mud deposition prominent in nearshore embayments. Lagoonal conditions occur between the Malus Islands and between Gidley and Legendre Islands.

Topographically, these inner islands resemble the hills of the adjacent mainland. Most are steep and rugged, with coastal cliffs and steep piles of volcanic and other igneous rocks separated by valleys, beaches and coastal sand-plains. They are vegetated sparsely and covered generally by Spinifex, Triodia spp (Semeniuk et al., 1982). The landward margins of the beaches are often backed by sparsely-vegetated sand dunes that rise to a height of $3 \mathrm{~m}$.

Significant Aboriginal rock art sites occur on many of the rock-pile islands as well as on the Burrup Peninsula. Some islands support relict populations of plants and animals representative of the mainland biota and thus have very high conservation values. Several of the beaches are important marine turtle nesting sites (e.g. Rosemary Island), migrating shore birds utilize the salt marshes, extensive mud flats and intertidal reefs and some of the small, outer islands and rocks support large seabird colonies.

Most (25) of the islands of the Dampier Archipelago are nature reserves under the jurisdiction of the National Parks and Nature Conservation Authority (NPNCA) and managed by the Department of Conservation and Land Management (CALM). The Lewis Islands and part of Malus Island are reserves for conservation and recreation and are also vested in the NPNCA.

The Dampier Archipelago provides a great diversity of habitats, both terrestrial and marine, the latter being the subject of the present study. For example, the seaward reefs of Kendrew, Rosemary, Legendre and Delambre Islands are exposed to considerable wave action whereas inlets on the Burrup Peninsula, such as Withnell Bay, are sheltered. There are shores with different aspects, substrata, topography and slope and which experience varying current patterns, turbidity and temperature regimes. Such diverse biological habitats support correspondingly diverse marine biotic assemblages.

The Burrup Peninsula covers an area of some 88 $\mathrm{km}^{2}$ northeast of the town of Dampier. The "Peninsula" is actually an island separated from the mainland by a tombolo of intertidal mudflats. This low-lying ground, known as Roo Cove, is the site of the salt evaporators associated with the Dampier Salt Ltd. mineral leases. Regional fracture trends (orientated NW-SE, ENE-WSW and NNE-SSW) have resulted in major valley systems which separate Dolphin Island from the Burrup Peninsula, segment the Angel-Gidley Island chain into its components and partly segment Dolphin Island. The valleys are filled to varying extents with sedimentary material. The channels that occur between islands comprise former valleys experiencing varying degrees of infilling. For example, Flying Foam Passage is largely un-filled, Searipple Passage is filled by limestone to low neap tide levels and King Bay to levels of low supratidal and high tidal levels by limestone, soils and marine sediments.

West of the Dampier Archipelago, the coast is dominated by mangrove habitats, mainly of the tidal creek, spit/chenier and alluvial fan assemblages (Semeniuk and Wurm, 1987). The Maitland River has a well developed mangal fronted by mudflats and the shallow, muddy waters of Regnard Bay. It is a typical example of a Pilbara river, discharging only for short periods during the summer months.

Nickol Bay is a large $\left(700 \mathrm{~km}^{2}\right)$, shallow, muddy, marine embayment bordering the eastern side of the Dampier Archipelago. The Burrup Peninsula and a chain of islands, Dolphin, Gidley, Angel and Legendre, separate the Dampier Archipelago from Nickol Bay. The uniform seafloor gently slopes from the southern margin of the bay to a depth of $20 \mathrm{~m}$ at the northern margin, where Delambre and Haüy Islands are emergent. Rocky shores, limestone pavements, tidal flats, mangroves and dunes demarcate the shores of Nickol Bay. Most of the western shore of the bay (i.e. the eastern side of the Dampier Archipelago) is characterised by rocky shores, with small bays and beaches and some fringing mangroves, e.g. Watering, Cowrie and Hearson Coves, and is comparable to similar shores on the western side of the Burrup Peninsula, such as Withnell Bay, and some of the inner islands of the archipelago, for example, Enderby Island. Southern and eastern bay shores, however, are characterised by wide mudflats and rich mangrove stands.

\section{Climate}

The climate of the Dampier Archipelago is described as tropical semi-desert (Bagnouls and Gaussen, 1957), pseudo-monsoonal (Gentilli, 1971), tropical and arid (Gentilli, 1972) or tropical arid (Semeniuk and Wurm, 1987). The climate is severe; temperatures may be high, rainfall is erratic and low and evaporation exceeds it throughout the year.

\section{Air temperature}

The adjacent sea mass moderates the temperature of the Dampier Archipelago compared to inland Pilbara regions. There are two distinct seasons - a warm, dry winter (June-September) and a hot, wetter summer (October-April/May). Winters are mild with mean maximum and minimum temperatures in July of $26.3^{\circ} \mathrm{C}$ and $14.0^{\circ} \mathrm{C}$, respectively. Summers are hot, with temperatures at Dampier sometimes exceeding $47^{\circ} \mathrm{C}$. Mean 
maximum and minimum temperatures in February are $37.1^{\circ} \mathrm{C}$ and $26.4^{\circ} \mathrm{C}$, respectively (Semeniuk and Wurm, 1987).

\section{Rainfall}

Annual rainfall is low and the evaporation rate high. Rainfall is seasonal but very unreliable and directly influences freshwater seepage (Semeniuk, 1983). The area has a $315 \mathrm{~mm}$ average annual rainfall with a mean of approximately 33 rainy days annually (Gentilli, 1972; Bureau of Meteorology, 1973, 1988). The Dampier Archipelago is subjected to periodic cyclones that occur predominantly between December and April. There are two peaks in rainfall, the first from January-March and a second from May-June. Freshwater input to the area, however, is generally limited since no major rivers empty into the immediate vicinity. Annual evaporation is $3,518 \mathrm{~mm}$ with a mean monthly minimum of $384 \mathrm{~mm}$ during December and a mean monthly minimum of $193 \mathrm{~mm}$ during July. Evaporation exceeds rainfall by a factor of nine in all months of the year.

\section{Relative humidity}

The highest humidities occur during the summer months averaging $48 \%$ at 0900 hours and $43 \%$ at 1500 hours.

\section{Winds}

Two significant wind regimes are associated with winter and summer (Steedman 1985). The southeast trades predominate between April and August and then change to monsoon winds from the west and southwest from September to March (Holloway and Nye, 1985). In general, easterly winds in winter have a pronounced diurnal pattern, increasing in speed (often $>20$ knots) during the morning to early afternoon before abating and changing to northwesterly sea breezes in the late afternoon to early evening (Gentilli, 1971, 1972; Bureau of Meteorology, 1973, 1988). This is in contrast to the summer pattern of prevailing westerly winds which blow persistently day and night (Steedman, 1985). Periods of variable winds and general calms occur during April and August with the changeover of these seasonal wind patterns (Mills et al., 1986).

\section{Tropical cyclones}

During the summer (December-April), tropical cyclones sometimes generate substantial rainfall, strong destructive winds and storm surges along the Pilbara coast. During April 1989, tropical cyclone Orson crossed the Pilbara coast $50 \mathrm{~km}$ west of Dampier resulting in a tidal surge $3.1 \mathrm{~m}$ above normal high tide level in King Bay. The strongest winds ever recorded in Australia (260 km/hour) were those of tropical cyclone John. This cyclone of intensity category five was one of the most powerful to hit Australia, crossing the Pilbara coast on 15 December 1999. On April 20 2002, category four tropical cyclone Rosita crossed the northwestern Australian coast $40 \mathrm{~km}$ south of Broome. On average, two cyclones cross the coast each year between Onslow and Broome, every 2-3 years a cyclone passes within $100 \mathrm{~km}$ of the Pilbara coast and within $150 \mathrm{~km}$ every 5-10 years (Coleman, 1971; Lourensz ,1981).

\section{Oceanography}

\section{Waves}

The Dampier Archipelago lies on the inner part of the North West Shelf. Long period swells, originating in the Southern Indian Ocean, are refracted by the regional bathymetry. Swell waves approach the Dampier Archipelago from the north, northwest and west and impinge on the outer, seaward reefs and subsequently around the complex bathymetry and islands. Southerly facing coasts, embayments, straits and inter-island passages are protected from swells (Semeniuk et al., 1982). Climatic conditions also influence the direction of oceanic long period swells as well as the localised smaller wind generated waves. In summer, tropical cyclonic disturbances (December to April) may generate large waves and increased wave action, which can have a destructive influence on coral communities in the Dampier Archipelago (Marsh, 1978). When cyclones pass to the west of the archipelago, swell waves may penetrate into areas, such as the southern end of Mermaid Sound, which are normally protected from long period wave action (Simpson, 1988). Wind-generated waves are small, usually less than $1.3 \mathrm{~m}$ in height and are generated by local winds. In the summer, waves arise mainly from the southwest, northwest and southeast and in the winter from the northeast, east, southeast and northwest (Semeniuk et al., 1982).

\section{Seawater temperatures and salinity}

Seawater temperature records for the outer $(37 \mathrm{~m}$ depth) and inner (11 $\mathrm{m}$ depth) waters of the Dampier Archipelago indicate that the annual range is approximately $22-30^{\circ} \mathrm{C}$ and $20-30^{\circ} \mathrm{C}$, respectively, with minimum and maximum readings occurring in July/August and February/ March (Woodside Petroleum Development Pty. Ltd, $1979 a, b)$. Seawater temperatures in shallow embayments such as Withnell Bay, however, can range from $18^{\circ} \mathrm{C}$ in winter to $34^{\circ} \mathrm{C}$ in summer, stressing corals at both extremes. Surface salinity values for nearshore and coastal waters in the Dampier Archipelago are generally close to oceanic $(36 \%$ ). Similarly, maximum salinity values are close to oceanic with summer maxima in the range of 36 
37\% (Woodside Petroleum Development Pty. Ltd, $1979 a, b)$. Interstitial and ponded waters of intertidal areas, however, exhibit marked variations in salinity (Semeniuk et al., 1982).

\section{Tides and currents}

Tides in the Dampier Archipelago are macrotidal and semidiurnal (Easton, 1970). The maximum tidal range is $5.1 \mathrm{~m}$; the mean spring range is $3.6 \mathrm{~m}$ and the mean neap range is $1.0 \mathrm{~m}$ (Australian Hydrographic Service 2000). The highest annual tides and tidal ranges occur during the equinoxes, while smallest neap tides occur around the time of the winter solstice (Gordon, 1987). Storm surges may increase the tidal range by an average of $2.0 \mathrm{~m}$ during cyclonic activity.

Circulation patterns in the Dampier Archipelago are influenced markedly by tidal action due to its large amplitude and there are strong currents among the islands. Some islands are regularly divided into two or more smaller ones by spring tidal activity, e.g. Goodwyn and Malus. The outer islands are bathed by moderately clear water, while inshore conditions are fairly turbid and there is often a distinct boundary between clear outer and turbid inner waters. A hydrodynamic model of water circulation for the Dampier Archipelago was developed by Mills (1985). Data on the tidal dynamics and currents of the Dampier Archipelago were reported on by Pitt and Mills (1985) and Mills et al. (1986) and, more specifically, data on suspended matter in Mermaid Sound by Forde (1985).

Water clarity in the Dampier Archipelago is related to physical and biological processes and varies both temporally and spatially (Forde 1985). Waves, winds and tidal currents appear to dominate mixing. In inshore regions, suspended organic detritus, particulate sediment and plankton are the causes of turbidity. Fine sediments resuspended by waves reduce water clarity during the December to March period and generally sediment deposition and light attenuation in winter (May to August) is less than in summer (December to March) (Forde, 1985). Blooms of the planktonic blue-green alga, Trichodesmium erythraeum (Creagh, 1985), coral mucus and other organic particulate matter all contribute to an increase in turbidity during the December to March period (Creagh, 1985).

The photic zone of the offshore inner North West Shelf can be over $50 \mathrm{~m}$, in contrast to the adjacent inshore waters of the Dampier Archipelago where it is generally less than $20 \mathrm{~m}$ (Simpson, 1988). The proximity of the open ocean modifies the physical environment of the outer reefs on the periphery of the archipelago. Extensive coral reef structures, for example, are confined to this area of the Dampier Archipelago. Corals also occur as small fringing or patch reefs adjacent to islands and rocky shores. Coral communities are common in the near shore zone (e.g. Mermaid Sound) and a different suite of corals is only found in turbid inshore waters on the Burrup Peninsula, Sea Ripple Passage and on Dampier town coast (Marsh, 1978).

\section{Regional Coastal Morphology}

Jutson (1950) referred briefly to the marine environments of the Dampier Archipelago in a regional report and coined the term "Pilbaraland" for the area now known as the Pilbara.

Based on geomorphology and oceanography, Semeniuk et al. (1982) divided the coastline around Dampier into five main regional units, namely Hinterland, the Oceanic Zone, the Nickol Bay Complex, the Maitland Delta Complex and the Dampier Archipelago. These authors further described the Dampier Archipelago in more detail, subdividing it into four morphological units characterized by depth, general physiography and substratum type (rocks and sediments). The units (submarine plains; islands; rocky reefs, coral reefs and shoals; and channels, straits and embayments) formed the framework for a broad classification of coastline types. A range of geomorphic units within the archipelago, differentiated mainly on the basis of substratum type, geometry, surface features and tidal levels, were also described. The units (intertidal and subtidal rocky shores, intertidal and subtidal limestone pavements, intertidal flats and beaches, and subtidal shoals and plains) could be further divided into habitat types on the basis of substratum differences and detailed geometry.

Semeniuk and Wurm (1987) provided several insights into mangroves and their habitats in the Dampier Archipelago. They described large-scale coastal types such as connective tidal lands, for example West Intercourse Island, and embayments and straits such as Noname Creek and King Bay. Also described were 13 medium scale coastal geomorphic units. These were: muddy tidal flat, sandy tidal flat, rocky-boulder shore, spit and chenier fringe, sandy beach, hinterland fringe, gravelly tidal flat, high tidal alluvial fan, mid tidal alluvial fan, tidal creek, tidal dune margin, high tidal lagoon, shoal and limestone pavement. Semeniuk and Wurm (1987) also provided detailed descriptions of King Bay, Withnell Bay, Conzinc Bay, Searipple Passage, Angel, Gidley and Enderby Islands and the Malus, Lewis and West Intercourse Island groups and areas.

\section{The Nearshore Marine Biological Environments}

The flora and fauna and nearshore environments of the Dampier Archipelago have considerable regional significance and are subject to increasing human impacts (Marine Parks and Reserves Selection Working Group, 1994). The various 
aspects of the marine environments of the Dampier Archipelago have, moreover, been described only relatively recently and prior to 1961 there was limited study of its fauna.

The main substratum types of the Dampier Archipelago are soft, unconsolidated sediments and rocks. Such sediments range from clays to gravels. Rocky substrata are of two types, Archaean-igneous and limestone. Locally, the latter is plastered onto the igneous basement and thus both rock types occur throughout the archipelago. In general, soft sediments favour a burrowing marine fauna, e.g. polychaete worms, molluscs, crustaceans, echinoderms and flora such as seagrasses, whereas hard substrata favour an encrusting biota, such as corals, molluscs (e.g. oysters and mussels) and marine algae.

In their paper describing the marine environments of the Dampier Archipelago, Semeniuk et al. (1982) demonstrated that most marine habitats and faunal assemblages are widespread along the shores of the Burrup Peninsula. A range of tidal and subtidal substrata occur within exposed and semi-protected areas along virtually every shoreline of the Dampier Archipelago. Complex distribution patterns occur in the nearshore and tidal environments and some marine habitats may be further modified by, for example, corals, sponges and mangroves. This results in an increase in habitat complexity and a concomitant increase in the diversity and density of biota that is able to be supported.

\section{Common marine habitats of the Dampier Archipelago}

\section{Rocky shores and limestone platforms*}

(*aterial for this and the Watering Cove section compiled by Professor Brian Morton, The University of Hong Kong, China, and Professor J. C. Britton, Texas Christian University, Texas, USA)

One of the most common habitats in the Pilbara is the widespread array of rocky shores (Semeniuk and Wurm, 1987), developed either along waveexposed portions of islands or as headlands which flank embayments, and thus experiencing various degrees of exposure to wave action. These shores are sometimes steep, with cliffs, or flat pavements, both alternating with moderately inclined boulder shores. Examples are King and Conzinc Bays, and Angel, Gidley, Enderby and the Lewis Islands. An oyster-barnacle zone occurs between mean sea level and high neap tide, and along the western shores of the Burrup Peninsula this zone is the main intertidal feature. Subtidal rocky habitats extend to $8 \mathrm{~m}$ depth and boulder slopes are common (Semeniuk te al., 1982; Semeniuk and Wurm, 1987).

Moderately to gently inclined limestone pavements may be either intertidal, e.g. along rocky portions of island embayments, or underlie shallow, subtidal areas (as subtidal extensions of tidal limestone pavement), where they may be covered by a veneer of sand. They are developed along the flanks of embayments and occur as extensive shoals within the outer archipelago as well as in protected nearshore embayments. Limestone intertidal flats are a feature of the outer islands with algal covered surfaces in the inner zone and corals on the outer zone. Their inner margins are undercut (notched).

Frequency of inundation is twice daily at MSL to fortnightly at MHWS. Limestone pavements harbour the most diverse assemblage of sponges, molluscs, crustaceans, corals and benthic algae. Examples of limestone pavements are at Withnell Bay, Searipple Passage, and Angel, Gidley and Enderby Islands. Subtidally, gently inclined limestone pavements extend to a depth of $8 \mathrm{~m}$ or more on island margins, embayments and channels (Semeniuk et al., 1982).

An example of a moderately exposed rocky shore is the karsted limestone platform seaward of Watering Cove (Figures 3 and 4A, B).

\section{Description of Watering Cove, Burrup Peninsula}

Watering Cove is a small embayment on the eastern side of the Burrup Peninsula, opening into Nickol Bay. Mangroves fringe its landward, western margin. Most of the central, intertidal portion of the cove is dominated by unconsolidated sediments inhabited by a variety of infauna (Taylor and Glover, 2003) and scavenging gastropods which emerge to forage during low tide periods (Morton and Britton, 2003). Blocks of limestone bedrock rise above the sediments, especially and progressively toward the mouth of Watering Cove. To the northeast, the seaward margin of Watering Cove is fringed by a broad, flat, limestone platform. Along the northern margin of the cove and somewhat further along the coast in general, spring tides expose the platform for 200 metres or more seaward of a vertical, microkarsted, limestone escarpment. The southeastern seaward margin of Watering Cove comprises large blocks of red basalt which have tumbled down upon the coastal limestone bedrock from adjacent hillsides.

The limestone escarpment rises abruptly a little more than $2 \mathrm{~m}$ above the platform floor (Figure 3). In sharp contrast to the dense fractured red basalt blocks which characterise much of the Pilbara region of Western Australia and the hillsides visible from this shore, the low limestone cliff seems strangely out of place. It is clearly of marine biogenic origin, an emergent and eroding remnant of what was a late Pleistocene subtidal reef (Kojan, 1994). Subaerial erosion has carved sharp pinnacles along the cliff face and gouged numerous crevices in which a variety of intertidal life finds refuge. Along the base of the cliff, at approximately MTL, 


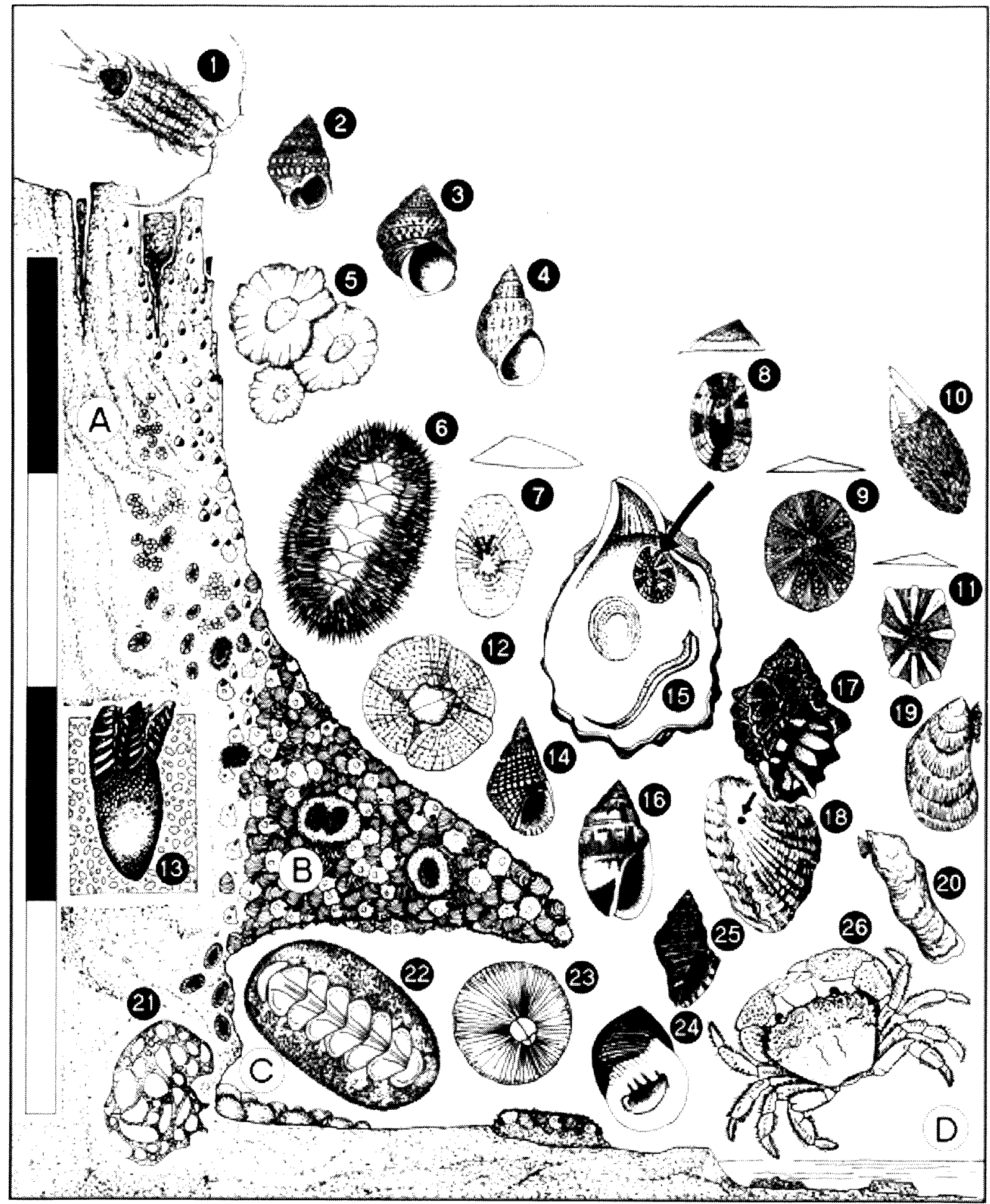

Figure 3 A profile of the karsted limestone platform at Watering Cove, Western Australia. The characterizing species and their broad vertical distributions are identified. The vertical scale on the left is divided into $0.5 \mathrm{~m}$ units. $\mathbf{A}$, is the high intertidal littorine and chthamalid zone; $\mathbf{B}$, the high eulittoral oyster, balanoid barnacle and limpet zone; $\mathbf{C}$, the low eulittoral wave cut notch beneath the oyster visor and $\mathbf{D}$, the low intertidal platform (not illustrated). 1, Ligia australiensis Dana, 1853; 2, Nodilittorina trochoides (Gray, 1839); 3, Nodilittorina vidua (Gould, 1859); 4, Littoraria cingulata (Philippi,1846); 5, Chthamalus malayensis Pilsbry 1916; 6, Acanthopleura spinosa (Bruguière, 1792); 7, Siphonaria zelandica Quoy and Gaimard, 1833; 8, Patelloida mimula (Iredale, 1924); 9. Cellana radiata (Born, 1778); 10, Ibla cumingi Darwin, 1851; 11, Patelloida saccharina (Linnaeus, 1758); 12. Balanus cirratus (Darwin, 1854); 13, Lithotrya zalentiana (Gray, 1825); 14, Planaxis sulcatus (Born, 1780); 15, Pomatoleios kraussi Baird, 1865; 16. Cronia avellana (Reeve, 1846); 17, Morula granulata (Duclos, 1832); 18, Saccostrea cucullata (Born, 1778) with drill-hole made by Morula gramulata (Duclos, 1832); 19, Brachidontes ustulatus (Lamarck, 1819); 20, Isognomon legumen (Gmelin, 1790); 21, Hydroclathrus clathratus (C. Agardh) Howe; 22, Acanthopleura gemmata Blainville, 1825; 23, Tetraclita squamosa (Bruguière, 1789); 24, Nerita tmdata Linnaeus, 1758; 25, Cronia margariticola (Broderip, 1833); 26, Eriphia sebana (Shaw and Nodder, 1803). 

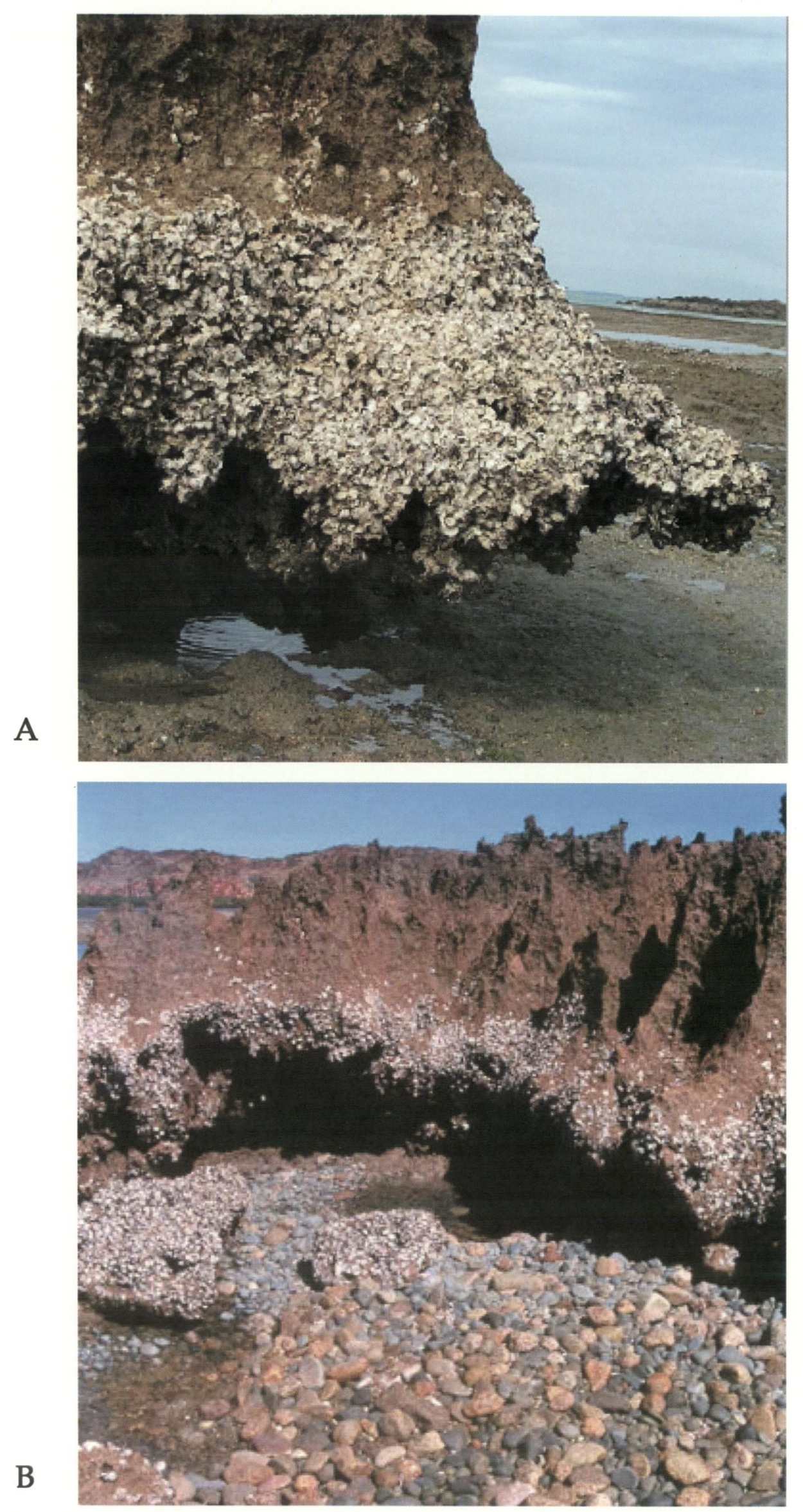

Figure 4 Watering Cove, Western Australia, showing: A, base of the cliff, at approximately MTL, where wave action has formed deep alcoves separated by uneroded spurs or pillars and B, gallery-like chambers created on the floor of the notch, both with a "visor" of progressive rock oyster (Saccostrea cucullata) growth. 
waves have undercut some sections, forming deep alcoves separated by uneroded spurs or pillars (Figure 4A).

The maximum and minimum tidal heights at Dampier, Western Australia are $\sim 0.1 \mathrm{~m} \mathrm{CD}$ and $\sim 4.9 \mathrm{~m} \mathrm{CD}$, giving a maximum theoretical range of $\sim 4.8 \mathrm{~m}$ (Australian Hydrographic Service 2000). That portion of the Watering Cove shore illustrated in Figure 3, therefore, represents the upper eulittoral and supralittoral fringe, with the vertical scale on the left of the figure divided into $0.5 \mathrm{~m}$ bars. As tidal benchmarks, the top of the conspicuous, $1.1 \mathrm{~m}$ tall, rock oyster zone is located $\sim 2.6 \mathrm{~m}$ below EHWST and the bottom, $\sim 1.2 \mathrm{~m}$ above ELWST.

The upper surface of the escarpment, although highly eroded and pitted, is nearly horizontal with only a gentle upward slope toward the land. The isopod Ligia australiensis Dana, 1853 hides within the deep upper platform crevices and two highzoned littorinids, Nodilittorina trochoides (Gray, 1839 ) and $N$. vidua (Gould, 1859), find shelter among shallow pits and grooves. The upper limit of a third littorinid, Littoraria cingulata (Phillipi, 1846) also occurs here. It shares the upper $0.5 \mathrm{~m}$ of the vertical surface of the escarpment with Chthamalus malayensis Pilsbry, 1916 in shaded crevices. This zone marks the top of the eulittoral and the bottom of the supralittoral fringe. Moving downward, three limpets appear in succession, the pulmonate Siphonaria zelandica Quoy and Gaimard, 1833, the patellid Cellana radiata (Born, 1778) and the lottiid Patelloida saccharina (Linnaeus, 1758), the latter with seven distinctive shell rays. At this level amongst the limpets and lower, the grazing chiton Acanthopleura spinosa (Bruguière, 1792) shelters at low tide periods within crevices (Britton and Morton, 2003). Here, too, is the balanoid barnacle Balanus cirratus (Darwin, 1854), occurring either as solitary individuals or in clumped aggregations.

The middle eulittoral is characterized by the rock oyster Saccostrea cucullata (Bom, 1778). The species has a focused zone of settlement that projects seaward from the escarpment face. The projecting mass of oysters consists of a base of empty, cemented shells covered with a veneer of living individuals. In several places, successive recruitments of oysters to the projecting mass have weakened its basal attachment such that large blocks of shells fall of and lie on the platform floor below. The oyster zone, moreover, is either undercut by waves or recruitment of oysters to the lower margin is impeded (more likely, both) so that the bottom of the escarpment has the appearance of an oyster shell "visor" covering a wave-cut notch. The beach veneer is not of fallen rocks, however, as on a more typical shore, but of living blocks of oysters. The wave-cut notch lies at approximately mean tide level (MTL), i.e. $\sim+2.4 \mathrm{~m} \mathrm{C.D.} \mathrm{and,} \mathrm{thus,}$ establishes another tidal benchmark between the escarpment and seaward platform.

The composition of the eulittoral oyster community is influenced by the oyster drill Morula granulata (Duclos, 1832) (K. S. Tan, pers. comm.). When the upper, drilled valves are lost, the lottiid limpet Patelloida mimula (Iredale, 1924) and the serpulid polychaete Pomatoleios kraussi (Baird, 1865) occupy the cup-shaped lower valves. Acanthopleura spinosa seeks shelter within pockets scattered among the mass of oyster shells in densities of up to three individuals per recess. There are also three distinctive oyster nestlers here: the bivalves Brachidontes ustulus (Lamarck, 1819) and Isognomon legumen (Gmelin, 1790) and the barnacle Ibla cumingi Darwin, 1851. Three gastropods can be found among the oysters including the littorinidlike grazer Planaxis sulcatus (Born, 1780) and two predatory muricids, Cronia avellana (Reeve, 1846) and $C$. margariticola (Broderip,1832), the latter known to feed on chitons in Hong Kong (Taylor and Morton, 1996). Also at this level, the boring barnacle Lithotrya valentiana (Gray, 1825) occupies the basal limestone rock.

Bare rock in the wave-cut notch provides settlement sites for the barnacle Tetraclita squamosa (Bruguière, 1789). The roof of the notch generally marks the lower boundary for Acanthopleura spinosa, but the floor and vertical walls of the notch mark the upper limit of distribution of the second chiton, A. gemmata Blainville, 1825 . In this zone, the vertical distributions of the two species overlap broadly, but it is also clear that the mean vertical range of $A$. spinosa is higher on the escarpment than that of $A$. gemmata.

Bunches of the green alga Hydroclathrus clathratus (C. Agardh) Howe pattern the deep recesses of the wave-cut notch. Here, too, is the herbivorous gastropod Nerita undata Linnaeus, 1758, either as solitary individuals or in aggregated clumps. The red-eyed crab Eriphia sebana (Shaw and Nodder, 1803) occupies holes and crevices in the limestone escarpment and the floor of the notch. It is probably a bivalve predator. Beneath the oyster "visor", wave-moved stones, including a mixture of offshore cobbles and oyster clumps from above, accumulate on the floor of the notch, sometimes creating gallery-like chambers (Figure 4B). The presence of the stones, of course, accelerates erosion of the notches and galleries. Seaward of the floor of the notch, the lower eulittoral and subtidal fringe comprise the broad, ecologically complex, limestone platform.

\section{Intertidal sand and mudflats with mangroves*}

( ${ }^{*}$ Material for this and the Withnell Bay section compiled by Professor Brian Morton, The University of Hong Kong, China)

Intertidal flats of sand and mud are common on 
the Dampier Archipelago and extensive areas of such habitats occur throughout the region in the inner, protected components of large embayments. Muddy and sandy tidal flats are gently inclined $(1: 1,000-1: 5,000)$ and extend from MSL to MHWS. Flooding of the shores varies from twice daily at MSL to fortnightly at levels above MHWS. Groundwater and soil water show salinity gradients of $45 \%$ at MSL to $90-100 \%$ at MHWS (Semeniuk and Wurm, 1987). Examples are King, Conzinc and Withnell Bays, Searipple Passage and Angel, Lewis, Enderby (Zeta Bay) and West Intercourse Islands.

Salt flats are muddy substrata which occur generally at high spring tide levels (Semeniuk et al., 1982). Salt flats are situated landward of a fringe of mangroves, for example at King, Withnell and Conzinc Bays. Flooding of the area varies and is fortnightly at levels above MHWS. A film of bluegreen algae may coat the surface and halophytes, e.g. Halosarcia indica (Willd.), P.G. Wilson, $H$. pruinosa (Paulsen), P.G. Wilson, and Muellerolimon salicornisceum (F. Muell.) Lincz., may occur on the higher parts of the salt flat (Figures 5 and $6 \mathrm{C}$ ) Salinity varies from $40-90 \%$

Mangals (mangrove communities), comprising a variety of highly-adapted plant species, are productive ecosystems occurring at the interface between land and sea. The Pilbara region supports a small number of mangrove species (Aegialitis annulata R. Br., Aegiceras corniculatum (L.) Blanco, Avicennia marina (Forsk.) Vierh., Bruguiera exaristata Ding Hou, Ceriops tagal (Perr.) C. B. Rob. and Rhizophora stylosa Griff.), although these may cover a relatively large area. Mangals inhabit mostly muddy intertidal areas between mean sea level and high water throughout the Dampier Archipelago. In some locations, they colonise either rocky or sandy substrata in protected embayments. Small mangrove stands fringe the sheltered bays of some islands, eg. Flying Foam Passage and the southem bays of Enderby Island. They are most luxuriant, abundant and diverse in embayments (e.g. King Bay) and connective tidal-lands, such as West Intercourse Lsland, and coastal areas, e.g. between Maitland River and the Intercourse Islands, where there is an accumulation of mud. A large portion $\left(113 \mathrm{~km}^{2}\right)$ of the mangal between Dampier and West Intercourse Island has been removed for the establishment of salt evaporators.

The large mangrove/mudflat complex at Withnell Bay is an example of such shores on the Burrup Peninsula (Figures 5 and 6 ).

\section{Description of Withnell Bay, Burrup Peninsula}

In many respects, the large mangrove mudflat complex at Withnell Bay is typical of such shores on the Burrup Peninsula. It is illustrated in plan riew in Figure 5, from which it can be seen that the bay is some $600 \mathrm{~m}$ wide and over $200 \mathrm{~m}$ in perpendicular extent. It is also complex in its geomorphology. The northern and southern arms of the bay comprise a bedrock chenier fringe, anchoring between them the huge mass of the intertidal sandy/mudflat. The southern end of the bay is also characterized by a large gravel delta, comprising small boulders, cobbles and gravel that is riffled by an outflow of groundwater which has a salinity of $>40 \%$ and creates a stream which drains down the beach and is particularly obvious at low tide. North and south of this delta is a perpendicularly arranged habitat that has been described for the Burrup by Semeniuk and Wurm (1987). The back of the shore (Figure 6A) comprises a bank of supratidal sand which is here accumulated from two sources, that is, the arid land behind and as aeolian sand blown landwards by onshore winds. In front of this (Figure $6 \mathrm{~B}$ ) is a fringe of landward mangroves. There are six species of mangroves in Australia's northwest, but here three are seen, that is, Bruguiera exaristata, Ceriops tagal, and, mostly, Aricennia marina, the latter with characteristic rays of pneumatophores arising from the spreading root stock. In front of this is a salt flat (Figure 6C), which is superficially soft and sticky mud but with a hardpan beneath. There then follows a seaward fringe of mangroves which comprise Rhizophora stylosa and, again dominant, Avicennia marina (Figure 6D). Seaward of this is the intertidal sand and mudflat (Figure 6E), bisected by the gravel delta (Figure 6F). The most obvious faunal elements of Withnell Bay are also illustrated in Figure 6.

The supratidal sand is the sole domain of the large, omnivorous ghost crab Ocvpode ceratophthalma (Pallas, 1772) with deep, seawardfacing burrows. Older, large animals live higher up the shore, smaller juveniles lower down. The landward fringe of mangroves is characterized by three large animal species. Two of these are the burrowing sesarmine crab Neosarmatium meinerti (de Man, 1887) and the virtually terrestrial hermit crab Coenobita rariabilis (McCulloch, 1909). These cooccur with apparently immobile groups of the large mangrove gastropod Terebralia palustris (Linnaeus, 1767) reposing in the shade of the trees (Wells and Lalli, 2003).

The salt flat seaward of the higher-zoned mangrove stand is characterized by two gastropods, large numbers of the mud-feeding snail Cerithided largillierti (Philippi, 1848) and the dark pulmonate slug Onchidium damelit Semper, 1882. This area of the shore is also home to the fiddler crab Uea elegans George and fones, 1982. The seaward fringe of mangroves comprises two main habitats, the trees themselves and the pneumatophores, stones and mud of the floor beneath. In the trees, running up and down is the sea shater Ligia australiensis Dana, 1853. On the branches is the algal film feeding littorine, Littoraria articulata (Philippi, 18t6) and the chthamalid bamade Chthamalus malarensis Pilsbry, 


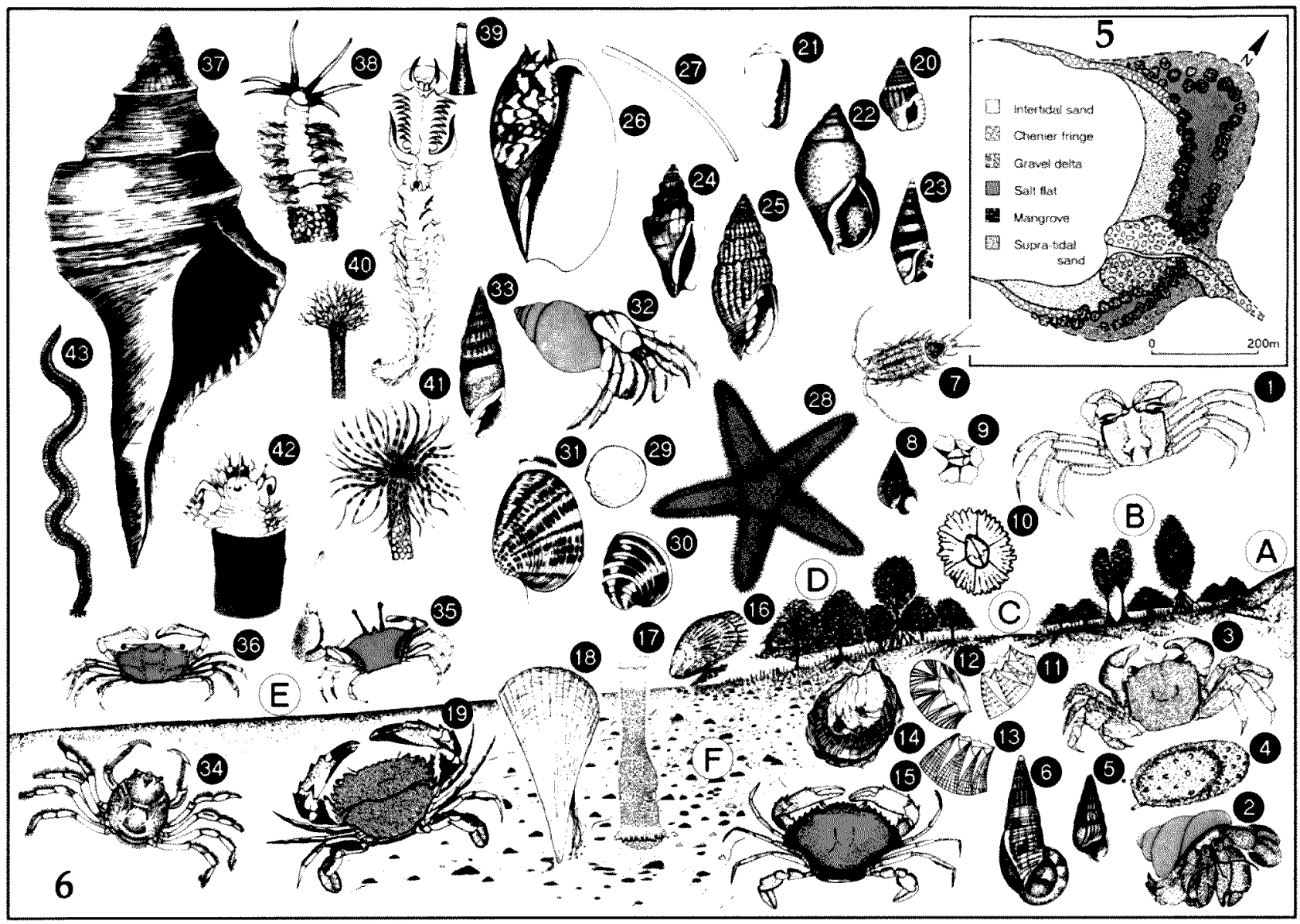

Figures 5-6 5 Withnell Bay, Western Australia, in plan view. 6 A profile of the mangrove and mudflat at Withnell Bay, Western Australia, showing: A, the rear supratidal sand; B, the mangrove of Bruguiera, Ceriops and Avicennia; C, the high intertidal salt flat; D, the seaward mangrove of Avicennia and Rhizophora; E, the intertidal sand and $\mathbf{F}$, represents the gravel delta. The illustrated species are: 1, Ocypode ceratophthalma (Pallas, 1772); 2, Coenobita variabilis McCulloch, 1909; 3, Neosarmatium meinerti (de Man, 1887); 4, Onchidium dämelii Semper. 1882; 5, Cerithidea largillierti (Philippi, 1848); 6, Terebralia semistriata Mörch, 1852; 7, Ligia australiensis Dana, 1853; 8, Littoraria articulata (Philippi, 1846); 9, Microeuraphia withersi (Pilsbry, 1916); 10, Chthamalus malayensis Pilsbry 1916;11, Balanus reticulatus Utinomi, 1967; 12, Balanus amphitrite Darwin, 1854; 13, Balanus cirratus (Darwin, 1854); 14, Saccostrea cuccullata (Born, 1778); 15, Scylla serrata (Forskål, 1775); 16, Brachidontes ustulatus (Lamarck, 1819); 17, Brechites vaginiferus (Lamarck, 1818); 18, Pinna muricata Linnaeus, 1758; 19. Thalamita crenata Rüppell, 1830; 20, Nassarius albinus (Thiele, 1930); 21, Mesoginella australis (Hinds, 1844); 22, Nassarius dorsatus (Röding, 1798); 23, Mitrella essingtonensis (Reeve, 1859); 24, Strombus urceus Linnaeus, 1758; 25, Vexillum amanda (Reeve, 1845); 26, Melo amphora (Solander, 1786); 27, Laevidentalium lubricatum (Sowerby, 1860); 28, Astropecten sumbawanus Döderlein, 1917; 29, Dosinia lucinalis (Lamarck, 1835); 30, Placamen gravescens (Menke, 1843); 31, Callista impar (Lamarck, 1818); 32, Diogenes avarus Heller, 1865; 33, Rhinoclavis vertagus (Linnaeus, 1758); 34, Mictryis longicarpus Latreille, 1806; 35, Uca mjoebergi Rathbun, 1924; 36, Macrophthalmus of crassipes H. Milne-Edwards, 1853; 37, Syrinx aruanus (Linnaeus, 1758); 38, Diopatra dentata Kinberg, 1865; 39, Chaetopterus variopedatus macropus Augener, 1914; 40, Lanice conchilega (Pallas, 1766) (tube); 41, Loimia ingens (Grube, 1878); 42, Polyodontes australiensis (plus tube) (McIntosh, 1885); 43, Phyllodoce madierensis Langerhans, 1880.

1916. An even higher-zoned barnacle is the tiny (2$3 \mathrm{~mm}$ diameter), almost non-calcified Microeuraphia withersi (Pilsbry, 1916). In the shade of the canopy, the rock oyster Saccostrea cucullata (Born, 1778) forms heavy cemented knobs on the pneumatophores and covers delta rocks. With it occur three barnacles, Balanus amphitrite Darwin, 1854, B. cirratus (Darwin, 1854) and B. reticulatus Utinomi, 1967, with the small dark mussel Brachidontes ustulatus (Lamarck, 1819). Here too occur the huge burrows of the Mangrove crab Scylla serrata (Forskål, 1755) with a right-handed crushing chela that easily cracks open the oysters, mussels and other shells.

The gravel delta rocks and cobbles are also covered in oysters and barnacles, but beneath them lives the predatory crabs Thalamita crenata Rüppell, 1830 and $T$. danae Stimpson, 1858. Sticking up from the interstitial mud are shells of the fan shell Pinna muricata Linnaeus, 1758 and careful searching in the riffle identifies the finger-sized apical openings of one of the rarest and strangest of all bivalves, the watering 
pot shell Brechites vaginiferus (Lamarck, 1818) (Morton 2002). This is one of only two known populations of this extremely rare animal which is so weird that its true shell valves are but $3 \mathrm{~mm}$ long indentations on an otherwise adventitious tube secreted with a "watering pot" like structure at its base.

On the intertidal mudflat is the greatest diversity of life. As one walks over the shore, footsteps inadvertently kill small inhabitants on the mud surface and to these corpses and the disturbed mud are attracted four scavenging snails, the nassariids Nassarius albimus (Thiele, 1930), the much larger $N$. dorsatus (Röding, 1798), the columbellid Mitrella essingtonensis (Reeve, 1859) and the tiny white marginellid Mesoginella australis (Hinds, 1844). The former two will readily attack damaged "prey" and the latter are probably camivorous but on what is unknown (Morton and Britton, 2003). Also on the beach are three larger gastropods, the deposit feeding Strombus urceus Linnaeus, 1758, Vexillum amanda (Reeve, 1845) tackling other gastropods by attacking them at the aperture, and the similarly deposit-feeding light brown cerithid mud snail Rhinoclaris vertagus (Linnaeus, 1758). A larger, more colourful predator is the apically-spiked volute Melo amphora (Solander, 1786) which feeds on other large gastropods by engulfing them. Infaunally, the commonest mollusc on the beach is the scaphopod Laevidentalium lubricatum (Sowerby, 1860) which uses sticky oral captacula to capture interstitial foraminiferans, particularly species of Ammonia and Quinqueloculina, on which is feeds (Glover et al., 2003). One of the more obvious predators on the beach is the large dullcoloured starfish Astropecten sumbaruanus Döderlein, 1917. This starfish feeds on small bivalves by everting its stomach and ingesting them. Some of its bivalve prey are illustrated, including Dosinia lucinalis (Lamarck, 1835), Placamen gravescens (Menke, 1843) with raised concentric lamellae on its shell, and the larger Callista impar (Lamarck, 1818). Empty gastropod shells, such as those of Nassarius dorsatus (Röding, 1798), are the homes of two hermit crabs, Clibanarius virescens (Krauss, 1843) (not illustrated) and Diogenes avarus Heller, 1865.

A number of burrowing crabs occur at Withnell Bay. Only three are illustrated. Armies of the blue Soldier crab Mictyris longicarpus Latreille, 1806 emerge from their burrows as the tide recedes and follow it down to feed on the soft surface mud, sieving out organic particles with their mouthparts. Like Ocypode ceratophthalma (Pallas, 1772), these crabs are members of the Ocypodidae. Another genus of this family is here represented by Macrophthalmus of crassipes H. Milne-Edwards, 1853 , which builds horizontal burrows and also feeds on surface deposits. A final illustrated ocypodid species is Uca mjoebergi Rathbun, 1924, which colonizes sandy substrata at all shore levels.

There are five species of fiddler crab on the
Withnell Bay shore (Figure 7). High up on the shore Uca elegans occurs, with a brown, blue or green carapace and a long, "elegant", orange-red major chela in the male. The male often builds a distinctive chimney atop its burrow. The middle shore is dominated by Uca flammula Crane, 1975 with a dark carapace which is marginally bright red, as are its chelae and walking legs. In contrast Uca capricomis Crane, 1975, which shares this region of the shore, is darkly-coloured with a stout whitecream chela. The lower shore is home to Uca polita Crane, 1975 with a slate grey carapace and a rosepink major chela in the male. In contrast, the similarly low-zoned Uca dampieri Crane, 1975 has a dark carapace and a large stout male dominant chela, which is pink to red with a white "finger". As noted above, Uca mjoebergi ranges widely on sand substrata (George and Jones, 1982).

A final group of dominant animals on Withnell Bay beach is the polychaetes. A green species of Phyllodoce, possibly P. madeirensis Langerhans, 1880, is the most obvious errant polychaete on the shore, but others also occur. Chaetopterus variopedatus macropus Augener, 1914 lives in long, fibrous tubes deep in the mud with only the ends sticking up above the surface like short drinking straws. Diopatra dentata Kinberg, 1865 constructs fibrous tubes ornamented with pieces of shell and gravel which extend just above the surface of the mud at low tide. Lanice conchilega (Pallas, 1766) tubes have an apical crown of fibrous branches that are colonized by other animals, such as sponges and sea squirts. Loimia ingens (Grube, 1878) also has a shell- and gravel-adorned tube and extends a plume of mottled tentacles into the water to catch suspended particles. The little known polychaete, Polyodontes australiensis (McIntosh, 1885), lives deep inside baggy, black, silky tubes. This polychaete, and some of the others mentioned above, is the prey of the largest gastropod on earth - the impressive Syrinx aruanus (Linnaeus, 1758). This is a melongenid snail with a long muscular proboscis, which is used to gain access to the worms hidden deep below in their tubes. Specimens of Syrinx, some over $60 \mathrm{~cm}$ long, are common on Withnell Bay and are easily seen from a distance, humped over a depression in the mud with a Polyodontes tube at its centre (Taylor and Glover, 2003).

Withnell Bay is a virtually pristine and very diverse faunistic habitat. It is also particularly significant as it is home to two of the world's most endangered molluscs - the giant gastropod Syrinx auramus (Linnaeus, 1758) and the watering-pot bivalve Brechites vaginiferus (Lamarck, 1818)

\section{Sea grass beds; marine algae}

Seagrasses occur sparsely, in low diversity and low abundance, on shallow, unconsolidated sediments of sand and muddy sand; for example, in 


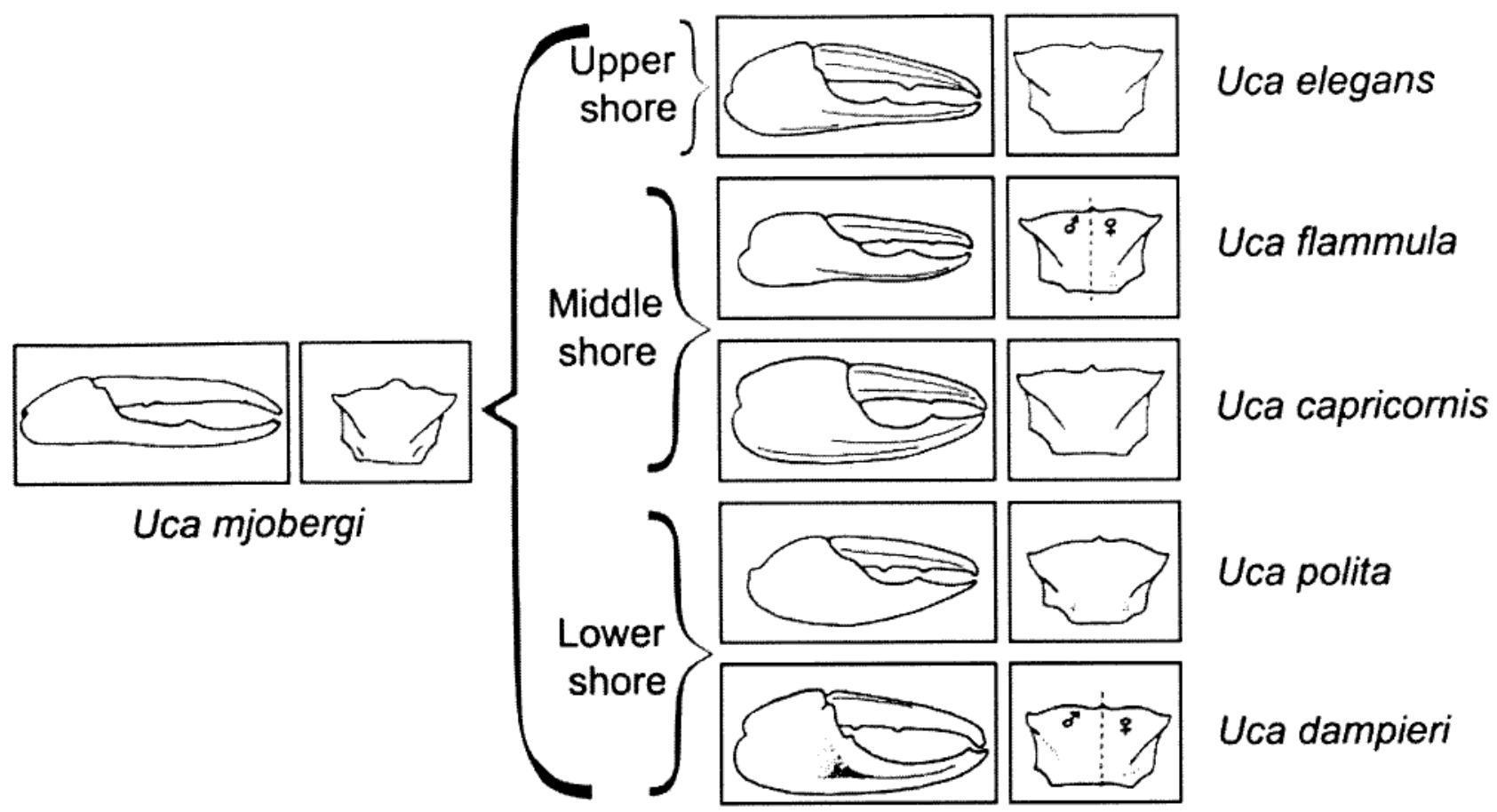

Figure 7 Fiddler crabs occurring on the shore of Withnell Bay, Western Australia.

the larger bays of the western shores of the nearshore environments of the Burrup Peninsula. A wide range of invertebrates such as corals, crustaceans, crabs, molluscs, holothurians and other echinoderms and demersal fishes are associated with this habitat. Macroalgae colonise shallow, subtidal, hard substrata, mainly in protected embayments (e.g. Conzinc Bay) or on shoals in the outer archipelago, or the inner zone of limestone intertidal flats of the outer islands.

\section{Coral reefs}

The archipelago has a diversity of corals, occurring mostly at depths between $0-10 \mathrm{~m}$. Veron and Marsh (1988) recorded 216 species of scleractinian corals from the area. A small suite of coral species (e.g. Pocillopora eydouxi Edwards and Haime, 1860) is confined to the outer reefs, for example, Kendrew Island that are exposed to considerable wave action. Others (e.g. Caulastrea tumida Matthai, 1928) occur only in turbid inshore waters, such as King Bay, but many of the species (e.g. Psammocora digita Edwards and Haime, 1851) range from inshore to offshore within the archipelago (Marsh, 1978; Paling, 1986a). Coral reef development is greatest on the seaward slopes of the outer archipelago, for example, at Kendrew Island. Typical fringing reefs are developed on the northwest side of Enderby Island, the seaward side of Kendrew Island, at Sailfish Reef, Hamersley Shoal and on the west and east slopes of Delambre Island. These rich reefs may have a lagoon and shallow back-reef, with a reef flat in front, and a reef-edge zone with a coral-rich, reef-front slope dissected by deep spurs and grooves. Corals do not form reefs in the inshore waters of the archipelago. Coral communities do, however, grow prolifically on solid substrata, for example on the subtidal rock slopes around Conzinc Island, the near shore of Mermaid Sound and along the western coast of the Burrup Peninsula.

The coral reefs of the Dampier Archipelago are a significant feature of the Pilbara marine environment and support diverse communities of fishes and marine invertebrates. This diversity is comparable to that of other parts of the Indo-Pacific coral province, with many species commonly shared. However, the faunal composition and community structure of these reefs is uniquely affected by the peculiarities of the geomorphology and biogeographical history of the Dampier Archipelago.

\section{Subtidal soft substrata}

A distinctive feature of the Dampier Archipelago is the soft substrata, mainly of mud and fine sand, of the sea bed. These substrata support an extremely diverse and rich benthic invertebrate fauna. This element of the marine fauna is documented for the first time in the present publication (Taylor and Glover, 2004).

\section{History of Research on the Marine Fauna and Flora of the Dampier Archipelago}

In 1699, William Dampier made what appear to be the first notes on the fauna, particularly turtles and seabirds, of the Dampier Archipelago (Dampier, 1703). Lamarck (1816) described 20 
coral species collected from Western Australia by Péron and Lesueur during the French Baudin Expedition (1801-1804), but sketchy locality data makes it impossible to know if any of these species were from the Dampier Archipelago. In 1818, during King's visit to the Dampier Archipelago, Alan Cunningham recorded some of the marine fauna (Lee, 1925). Again, however, although King (1827) listed 19 species of hermatypic corals, no locality data were included. A variety of sponges (Lendenfeld, 1907), corals (Studer, 1878), echinoderms (Studer, 1880, 1882, 1884; Lampert, 1889; Clark, 1909) and barnacles Weltner (1897) were collected from the Dampier Archipelago ("Meermaidstreet"), as well as from Shark Bay, by the German Gazelle Expedition (1874-76).

It was not until the early 1960s that research on the marine fauna and habitats of the Dampier Archipelago commenced in earnest. A Western Australian Museum expedition made extensive collections of invertebrates on the shores of Rosemary, Legendre and Delambre Islands in 1961, followed by a joint Western Australian Museum/ Western Australian Herbarium Expedition to the islands the following year (1962). A report on the Banana prawn nurseries near the Dampier Archipelago was completed by Slack-Smith (1967). In 1970, two teams from the Department of Fisheries and Fauna, which included Western Australian Museum scientists, surveyed the flora and fauna of the main islands of the archipelago which appeared likely to be disturbed by future industrial and tourist developments (Burbidge and Prince, 1972).

Between 1971 and 1974, seasonal surveys on aspects of the ecology of the coral predator Acanthaster planci (Linnaeus, 1758), the Crown-ofThorns Starfish, were conducted by the Western Australian Museum on the northwestern perimeter of the Dampier Archipelago. Coral reefs off Rosemary Island (1971) and Rosemary and Kendrew Islands (1972-74) were surveyed (Wilson, 1972; Wilson and Marsh, 1974, 1975, 1979; Wilson et al., 1974). During these surveys, faunal lists of the corals and other marine invertebrates were initiated and the first check-list of the fishes of the western portion of the Dampier Archipelago was compiled (Hutchins and Allen, 1978, unpublished ms.).

In 1978, the Western Australian Museum extended these studies with surveys of the marine flora, reef fishes, molluscs, and hard corals and associated invertebrates, of the Burrup Peninsula and nearby islands (Hutchins, 1978; Hutchins et al., 1978; Marsh, 1978; Slack-Smith, 1978a, b). These data contributed toward an unpublished report to Woodside Petroleum Development Pty. Ltd. (Meagher and Le Provost, 1979) and which, for the first time, brought together information on the physical and biological features of the Dampier Archipelago.

As part of a regional study of the mangroves of Western Australia, Semeniuk et al. (1978) identified the species of the Dampier Archipelago and demonstrated that only a small pool of six occurs in the region. Wilson and Marsh (1979) recorded 44 hermatypic coral genera from the Dampier Archipelago. Corals were again collected in 1983 by the Western Australian Museum in association with the Western Australian Department of Conservation and Environment. The latter conducted and supported extensive surveys of the marine habitats and fauna of the Dampier Archipelago between 1981-1986 in anticipation of industrial developments in the area and the potential for pollution. The objectives of the combined studies were detailed in a progress report (Chittleborough, 1983), the results of which formed an invaluable baseline for marine environmental planning and management. For example, some habitat mapping of the shallow zones of the archipelago was conducted (Chittleborough, 1982, 1983). Data on the tidal dynamics and currents of the Dampier Archipelago and, more specifically, on suspended matter in Mermaid Sound, were reported on by Pitt and Mills (1985) and Mills et al. (1986), and by Forde (1985), respectively. A vegetation map of the Dampier Archipelago was prepared by Thorman (1983). Information on the mangrove environments has been provided by (Bridgewater, 1982) and preliminary studies on the mangroves of the archipelago have been conducted by Gordon $(1983,1987)$. The ecological significance of the blue-green algal mats in the Dampier mangrove ecosystem were assessed and studied by Paling (1983, 1986b), Paling and McComb (1986) and Paling et al. (1989). A Dugong Dugong dugon (Müller, 1776) survey along the Pilbara coast in 1984 recorded up to 9 animals $/ 100 \mathrm{~km}$ of coastline in the Dampier to Onslow on-shore sector (Prince, 1986). Environmental factors affecting coral growth in the Dampier Archipelago were reported upon by Simpson (1985a), who also reported upon the mass spawning of corals (Simpson, 1985b), the first record of this event on the Western Australian coast.

In a paper describing the marine environments of the Dampier Archipelago, Semeniuk et al. (1982) presented detailed analyses of the main biotic assemblages present. The biota was segregated into 15 broad assemblages that were characteristic of broad habitat categories. These authors also gave a concise account of the geology and morphology of the archipelago. A detailed insight into the variability of mangrove environments and habitats of the archipelago was provided by Semeniuk and Wurm (1987).

In 1979, the Western Australian Museum 
collected crustaceans and molluscs from the shores of Nickol Bay and Mermaid Sound (George et al., 1979) and in a publication describing the fiddler crabs of Australia, George and Jones (1982) documented nine species occurring in the Dampier Archipelago. In 1987, a Western Australian Museum expedition collected molluscs, crustaceans and polychaete worms at Enderby Island, some offshore islands and the western side of the Burrup Peninsular (unpublished data, Western Australian Museum). Survey work carried out by CSIRO in 1983-1984 investigated the fish fauna of nearshore mangrove creeks and open shores of the Dampier area (Blaber et al., 1985) and an illustrated guide to the continental shelf fishes of northern and northwestern Australia was produced by Sainsbury et al. (1985).

From the coral community data of Marsh (1978), a number of reef sites in the archipelago were classified into several broad groups using multivariate techniques (Paling, 1986a). This author demonstrated that protected sites on the Burrup Peninsula had less species richness and hard coral cover than more exposed ones. Simpson (1988) recorded additional hard coral species from the Archipelago during a survey around Kendrew and Rosemary Islands, as well as Hamersley Shoal and outer Legendre Island. In the same year, Veron and Marsh (1988) published records and an annotated species list of the hermatypic corals of Western Australia: 216 species in 57 hermatypic coral genera were recorded from the Dampier Archipelago.

Further work on the Crown-of-Thorns Starfish in the Archipelago was conducted by the Western Australian Department of Conservation and Land Management (Wilson and Stoddart, 1988), the Australian Institute of Marine Science (Johnson and Stoddart, 1988) and the Western Australian Department of Conservation and Environment (Simpson and Grey, 1989). A three-part guide to fishing in the waters of the Dampier Archipelago was produced by Woodside Petroleum Development Ltd. (1986, 1989, 1992).

The Dampier Archipelago Nature Reserves Management Plan (Chevis et al., 1990) contained a recommendation that the waters of the archipelago should be declared a marine park but boundaries were not suggested. Four years later, a report on a proposed marine reserve system for Western Australia recommended that the waters of the Dampier Archipelago, excluding the inner portion of Mermaid Sound and the functional area of the Port of Dampier, be reserved for the purposes of public recreation and protection of flora and fauna, and that the boundary should be the limit of the State Territorial Sea (Marine Parks and Reserves Selection Working Group, 1994). In 1995, The Management Plan for the Dampier Archipelago Nature Reserves 1990-2000 was published (Morris, 1995). By
2005, the-Dampier Archipelago-Cape Preston Marine Conservation Reserve will, hopefully, be established (Osborne et al., 2002).

The Western Australian Mangrove Assessment Project (Pedretti and Paling, 2001) has recently provided a database for the mangroves of the four main regions of Western Australia (Kimberley, Pilbara, Gascoyne and South West) and includes 17 sites throughout the Dampier Archipelago and the adjacent hinterland. An associated internet site allows easy access to the database, digital maps and report.

Cruises by Davena (1960) and Lady Basten (1995) have also made collections of benthic fauna in the waters of the Dampier Archipelago and these are housed in the Western Australian Museum. However, the CSIRO trawling expeditions by Soela (1979-1984) in the nearby waters of the North West Shelf made few collections in the archipelago.

Until recently, there were few reports on the marine benthic flora of the Dampier Archipelago (e.g. Slack-Smith, 1978a) or the waters of northern Australia (Lewis, 1984; 1985; 1987) and this lack of information has been emphasised by Huisman et al. (1998). No comprehensive flora list for the archipelago has been compiled, but a number of publications have recently increased the species recorded from the region (e.g. Phillips et al., 1993; King and Puttock, 1994; Huisman, 1996; Phillips and Huisman, 1997; Phillips, 2000; Huisman, 2000; 2001).

Data on the marine fauna of the Dampier Archipelago have been included in a number of published taxonomic papers. The regional faunas have also been discussed in various zoogeographic accounts (e.g. Marsh, 1976; 1983). References to such publications are given in the papers that form the main contents of this report. A number of studies and reports concerning various aspects of the flora and fauna, oceanography and geomorphology of the Dampier Archipelago have been undertaken and written by various environmental consultants. This "grey literature" is unpublished and is not readily available to the general public. However, such data for the North West Shelf have recently been amassed as a reference compendium by the North West Shelf Joint Environmental Management Study (http:// epagate.environ.wa.gov.au/nws/bibliography.htm).

\section{ACKNOWLEDGEMENTS}

I sincerely thank my colleagues at the Western Australian Museum (members of the Department of Aquatic Zoology; Dr Paddy Berry, Director of Science and Culture; Mr George Kendrick, Emeritus Curator Department of Earth and Planetary Sciences; and Mr Mance Lofgren, Department of Anthropology) and Dr Graham Chittleborough, Dr John Keesing, Professor Brian Morton and Dr Barry 
Wilson for their pertinent comments which significantly improved drafts of the manuscript. I am most grateful to Professor Brian Morton, The University of Hong Kong, China, and Professor J. C. Britton, Texas Christian University, Texas, USA, who kindly contributed the 'Rocky shores and limestone platforms,' 'Description of Watering Cove, Burrup Peninsula,' 'Intertidal sand and mudflats with mangroves' and 'Description of Withnell Bay, Burrup Peninsula' sections of the paper. I also wish to acknowledge Mrs Margaret Triffit, Librarian, Western Australian Museum, for assistance with literature references.

\section{REFERENCES}

Australian Hydrographic Service. (2000). Australian National Tide Tables 2001. Australian Hydrographic Publication 11. Australian Government Publishing Service, Canberra. 406 pp.

Bagnouls, F. and Gaussen, H. (1957). Les climats biologiques et leur classification. Annales de Geographie 66: 193-220.

Biggs, E.R. (1979). Nickol Bay-Legendre, Western Australia: 1:50,000 scale Urban Geology Series. Geological Survey of Western Australia.

Biggs, E.R. (1980). Dampier-Eaglehawk Island-Rosemary, Western Australia: 1:50,000 scale Urban Geology Series. Geological Survey of Western Australia.

Blaber, S.J.M., Young, J.W and Dunning, M.C. (1985). Community structure and zoogeographic affinities of the coastal fishes of the Dampier region of northwestern Australia. Australian Journal of Marine and Freshwater Research 36: 247-266.

Bridgewater, P.B. (1982). Mangrove vegetation of the southern and western Australian coastline. Chapter 7: 111-120. In Clough, B. F. (ed.), Mangrove Ecosystems in Australia, Structure, Function and Management. Australian Institute of Marine Science/Australian National University Press, Canberra.

Britton, J.C. and Morton, B. (2003). Convective cooling by the tropical intertidal chiton, Acanthopleura spinosa (Mollusca: Polyplacophora) from rocky intertidal habitats at Watering Cove, Burrup Peninsula, Western Australia, Australia. In Wells, F.E., Walker, D.I. and Jones, D.S. (eds), Proceedings of the Eleventh International Marine Biological Workshop: The Marine Flora and Fauna of Dampier, Western Australia 1: 51-67. Western Australian Museum, Perth.

Burbidge, A.A. and Prince, R.I.T. (1972). The Fauna, Flora and Planned Usage of the Dampier Archipelago. Report 11: 1-27. Department of Fisheries and Fauna, Western Australia.

Bureau of Meteorology. (1973). The climate and meteorology of Western Australia. In Western Australian Year Book 12: 25-59. Melbourne.

Bureau of Meteorology. (1988). Climatic averages, Australia. Australian Government Publishing Service, Canberra. 532 pp.

Carr, B. and Livesey, N. (1996). Pilbara Mangrove Study. Volume 1 - Final Report to the Heritage Council of
Western Australia. Natural Environment Documentation Project of Western Australia Report 18: 1-101. Institute for Environmental Science, Murdoch University and Conservation Council of Western Australia.

Chevis, H., Morris, K., Padgett, A. and Oliver, G. (1990). Dampier Archipelago Nature Reserves Management Plan 1990-2000. Western Australian Department of Conservation and Land Management, Perth. $86 \mathrm{pp}$.

Chittleborough, R.G. (1982). Marine systems of the Dampier Archipelago: papers presented to a workshop convened by the Department of Conservation and Environment. Bulletin 109. Western Australian Department of Conservation and Environment, Perth. 35 pp.

Chittleborough, R.G. (1983). The Dampier Archipelago marine study: a progress report. Bulletin 141: 1-12. Western Australian Department of Conservation and Environment, Perth.

Clark, A.H. (1909). The crinoids of the Gazelle Expedition. Zoologischer Anzeiger 34: 363-370.

Coleman, F. (1971). Frequencies, tracks and intensities of tropical cyclones in the Australian region, November 1909-June 1969. Commonwealth Bureau of Meteorology, Australian Government Publishing Service, Canberra. $42 \mathrm{pp}$.

Creagh, S. (1985). Review of literature concerning blue-green algae of the genus Trichodesmium. Bulletin 197: 1-33. Western Australian Department of Conservation and Environment, Perth.

Dampier, W. (1697). A New Voyage round the World. James Knapton, London. 550 pp.

Dampier, W. (1703). A Voyage to New Holland, etc. in the Year 1699. James Knapton, London. 162 pp.

Department of Conservation and Land Management (CALM). (1994). A representative marine reserve system for Western Australia. Report of the Marine Parks and Reserves Selection Working Group. Department of Conservation and Land Management, Perth, Western Australia. 5 parts.

Easton, A.K. (1970). The tides of the continent of Australia. Horace Lamb Centre for Oceanographic Research, Research Paper 37. Flinders University, South Australia. 189 pp.

Forde, M.J. (1985). Technical report on suspended matter in Mermaid Sound, Dampier Archipelago. Bulletin 215: 1102. Western Australian Department of Conservation and Environment, Perth.

Gentilli, J. (ed.). (1971). Climates of Australia and New Zealand. World Survey of Climatology 13: 1-405. Elsevier Publishing Company, Amsterdam. 405 pp.

Gentilli, J. (1972). Australian Climate Patterns. Thomas Nelson Australia, Melbourne. 285 pp.

Geological Survey of Western Australia. (1980). Western Australia 1:50,000 Urban Geology Series Eaglehawk Island, Dampier, Bayton, Nickol Bay, Mt Wilkie sheets. Geological Survey of Western Australia.

George, A.S. (1971). The plants seen and collected in northwestern Australia by William Dampier. The Western Australian Naturalist 11: 173-178.

George, A.S. (1999). William Dampier in New Holland. Bloomings Books, Hawthorne, Victoria. $171 \mathrm{pp}$.

George, R.W. and Jones, D.S. (1982). A revision of the 
fiddler crabs of Australia (Ocypodidae: Uca). Records of the Western Australian Museum, Supplement 14: 199.

George, R.W., Wells, F.W. and Jones, D.S. (1979). Report on the Pilbara Mangrove Survey (23-30 June 1979) and an outline of future programs. Unpublished Western Australian Museum Report to Integrated Environmental Services. $8 \mathrm{pp}$.

Glover, E., Taylor, J. and Whittaker, J. (2003). Distribution, abundance and foraminiferal diet of an intertidal scaphopod, Laevidentatum lubricatum, around the Burrup Peninsula, Dampier, Western Australia. In: Wells, F.E., Walker, D.I. and Jones, D.S. (eds), Proceedings of the Eleventh International Marine Biological Workshop: The Marine Flora and Fauna of Dampier, Western Australia: 225-240. Western Australian Museum, Perth.

Gordon, D.M. (1983). A preliminary study of the mangroves of the Dampier Archipelago, Western Australia. Environmental Note 141. Western Australian Department of Conservation and Environment, Perth. $24 \mathrm{pp}$.

Gordon, D.M. (1987). Disturbance to mangroves in tropicalarid Western Australia: hyper-salinity and restricted tidal exchange as factors leading to mortality. Technical Series 12. Environmental Protection Authority, Perth, Western Australia. 36 pp.

Henn, P.U. (1934). French exploration on the Western Australian coast. Early Days 2: 1932-1936. Western Australian Historical Society.

Hickman, A.H. (1983). Geology of the Pilbara Block and its Environs. Bulletin 127, Western Australia Geological Survey. 267 pp.

Holloway, P E. and Nye, H.C. (1985). Leeuwin Current and wind distributions on the southern part of the Australian North West shelf between January 1982 and July 1983. Australian Journal of Marine and Freshwater Research 36: 123-137.

Huisman, J.M. (1996). The red algal genus Coelarthrum Børgesen (Rhodymeniaceae, Rhodymeniales) in Australian seas, including the description of Chamaebotrys gen. nov. Phycologia 35: 95-112.

Huisman, J.M. (2000). Marine Plants of Australia. University of Western Australia Press, Nedlands. 300 pp.

Huisman, J.M. (2001). Echinophycus minutus (Rhodomelaceae, Ceramiales), a new red algal genus and species from northwestern Australia. Phycological Research 49: 177-182.

Huisman, J.M., Cowan, R.A. and Entwisle, T.J. (1998). Biodiversity of Australian marine macroalgae - a progress report. Botanica Marina 41: 89-93.

Hutchins, J.B. (1978). The report of a reef fish survey conducted in the Dampier Archipelago during August, 1978: 1-51. In Hutchins, J.B., Slack-Smith, S.M. and Marsh, L.M. (eds), Report on the Marine Fauna and Flora of the Dampier Archipelago. Western Australian Museum, Perth. Unpublished reports submitted to Meagher and LeProvost, Consultant Biologists, December 1978.

Hutchins, J.B. and Allen, G.R. (1978). Provisional checklist of the fishes of the Dampier Archipelago. Western Australian Museum, Perth. Unpublished list.
Hutchins, J.B., Slack-Smith, S.M. and Marsh, L.M. (eds). (1978). Report on the marine fauna and flora of the Dampier Archipelago. Western Australian Museum, Perth. Unpublished reports submitted to Meagher and LeProvost, Consultant Biologists, December, 1978.

Johnson, D.B. and Stoddart, J.A. (1988). Report on surveys of the distribution, abundance and impact of Acanthaster planci on reefs within the Dampier Archipelago (Western Australia). Australian Institute of Marine Science Report. 15 pp.

Jutson, J.T. (1950). The Physiography (geomorphology) of Western Australia. Bulletin 95, Geological Survey of Western Australia. 366 pp.

King, P.P. (1827). Narrative of a survey of the intertropical and western coasts of Australia performed between the years 1818 and 1822. 2 Volumes. John Murray, London. $366 \mathrm{pp}$.

King, R.J. and Puttock, C.F. (1994). Macroalgae associated with mangroves in Australia: Rhodophyta. Botanica Marina 37: 181-191.

Kojan, C.J. (1994). The geology and mineral resources of the proposed Dampier Archipelago National Park. Record 1994/2: 1-43. Geological Survey of Western Australia, Department of Minerals and Energy.

Kriewaldt, M.J.B. (1964). Dampier and Barrow Island, Western Australia. 1:250 000 Geological Series. Explanatory Notes, SF/50-2 and SF/50-1, Geological Survey of Western Australia.

Lamarck, J.B.P.A. de M. de (1816). Histoire naturelle des animaux sans vertèbres 2: $1-568$. Paris.

Lampert, K. (1889). Die während der Expedition SMS Gazelle 1874-76 von Professor Dr Th. Studer gesammelten Holothurien. Zoologische Jahrbïcher (Systematik) 4: 806-858.

Lee, I. (1925). Early explorers in Australia. Methuin and Co. Ltd., London. 651 pp.

Lendenfeld, R. von (1907). Die Tetraxonia. In Chun, C. (ed), Wissenschaftliche Ergebnisse der Deutschen TiefseeExpedition auf dem Dampfer "Valdivia" 1898-1899 11: 59-374.

Lewis, J.A. (1984). Checklist and Bibliography of Benthic Marine Macroalgae recorded from Northern Australia. 1. Rhodophyta. Department of Defence Materials Research Laboratories, Melbourne. 97 pp.

Lewis, J.A. (1985). Checklist and Bibliography of Benthic Marine Macroalgae recorded from Northern Australia. II. Phaeophyta. Department of Defence Materials Research Laboratories, Melbourne. 40 pp.

Lewis, J.A. (1987). Checklist and Bibliography of Benthic Marine Macroalgae recorded from Northern Australia. III. Chlorophyta. Department of Defence Materials Research Laboratories, Melbourne. 55 pp.

Lorblanchet, M. (1989). Middens and Engravings, Dampier (Western Australia). Australian Institute of Aboriginal Studies, Canberra, A.C.T. Unpublished Report.

Lourensz, R.S. (1981). Tropical cyclones in the Australian region July 1909 to June 1980. Commonwealth Bureau of Meteorology, Australian Government Publishing Service, Canberra. 94 pp.

MacIlroy, J. (1979). Dampier Archipelago Historical Sites Surveys. Australian Heritage Commission. 105 pp. 
Marchant, L.R. (1998). An island unto itself: William Dampier and New Holland. Hesperian Press, Victoria Park. 208 pp.

Marine Parks and Reserves Selection Working Group. (1994). A Representative Marine Reserve System for Western Australia. Report of the Marine Parks and Reserves Selection Working Group, Department of Conservation and Land Management, Perth, Western Australia. 222 pp.

Marsh, L.M. (1976). Western Australian Asteroidea since H. L. Clark. Thalassia Jugoslavica 12(1): 213-225.

Marsh, L.M. (1978). Report on the corals and some associated invertebrates of the Dampier Archipelago: 1-67. In Hutchins, J.B., Slack-Smith, S.M. and Marsh, L.M. (eds), Report on the Marine Fauna and Flora of the Dampier Archipelago. Western Australian Museum, Perth. Unpublished reports submitted to Meagher and LeProvost, Consultant Biologists, December, 1978.

Marsh, L.M. (1983). Some aspects of the zoogeography of northwestern Australian echinoderms (other than holothurians). Bulletin of Marine Science 33: 671-687.

Meagher, T. and Le Provost, I. (1979) Marine Environment of Dampier Archipelago. Unpublished Technical Report to Woodside Petroleum Development Pty. Ltd., North West Shelf Project. 242 pp.

Merrilees, D. (1979). The prehistoric environment in Western Australia. Journal of the Royal Society of Western Australia 62: 109-128.

Mills, D.A. (1985). A numerical hydrodynamic model applied to tidal dynamics in the Dampier Archipelago. Bulletin 190: 1-30. Western Australian Department of Conservation and Environment, Perth.

Mills, D.A., Pitt, D.R. and Simpson, C.J. (1986). Summary of current meter data from the Dampier Archipelago 19811984. Environmental Note 178: $11 \mathrm{pp}+$ figures. Western Australian Department of Conservation and Environment, Perth.

Morris, K. (1995). Dampier Archipelago Nature Reserves Management Plan 1990-2000. Management Plan 18: 186. Department of Conservation and Land Management, Perth.

Morton, B. (2002). Biology and functional morphology of the watering pot shell Brechites vaginiferus (Bivalvia: Anomalodesmata: Clavagelloidea). Journal of Zoology, London 257: 545-562.

Morton, B. and Britton, J.C. (2003). The behaviour and feeding ecology of a suite of gastropod scavengers at Watering Cove, Burrup Peninsula, Western Australia. In Wells, F.E., Walker, D.I. and Jones, D.S. (eds), Proceedings of the Eleventh International Marine Biological Workshop: The Marine Flora and Fauna of Dampier, Western Australia: 147-171. Western Australian Museum, Perth.

Osborne, S., Bancroft, K., D'Adamo, N. and Monks, L. (2002). Dampier Archipelago/Cape Preston Regional Perspective 2000. Department of Conservation and Land Management, Perth, Western Australia. 74 pp.

Paling, E.I. (1983). The ecological significance, in relation to nutrient export, of blue-green algal mats in the Dampier mangrove ecosystem. Unpublished Honours Thesis, Department of Botany, University of Western Australia.
Paling, E.I. (1986a). Analysis of coral community data using multivariate techniques, and their application to other community data. Technical Series 3: 1-28. Environmental Protection Authority, Perth, Western Australia.

Paling, E.I. (1986b). The ecological significance of the bluegreen algal mats in the Dampier mangrove ecosystem. Technical Series 2: 1-134. Western Australian Department of Conservation and Environment, Perth.

Paling, E.I. and McComb, A.J. (1986). Cyanobacterial mats: a possible nitrogen source for arid coast mangroves. International Journal of Ecology and Environmental Sciences 20: 47-54.

Paling, E.I., McComb, A.J. and Pate, J.S. (1989). Nitrogen fixation (acetylene reduction) in non-heterocystous cyanobacterial mats from the Dampier Archipelago, Western Australia. Australian Journal of Marine and Freshwater Research 40: 147-153.

Pedretti, Y.M. and Paling, E.I. (2001). WA mangrove assessment project 1999-2000. Murdoch University, Perth. http://megatron.murdoch.edu.au/ wamangrove

Penn, J.W. ( 2002). State of the Fisheries Report 2000-2001. Department of Fisheries Western Australia, Western Australian Government. $198 \mathrm{pp}$.

Péron, F., Freycinet, L., Lesueuer, C.-A. and Petit, N.-M. (1807-1816). Western Australia "Voyage de découvertes aux Terres Australes, exécuté par ordre de Sa Majesté l'Empereur et Roi, sur les corvettes Le Géographe et le Naturaliste et la goëlette Le Casuarina, pendant les années 1800,1801,1802, 1803 et 1804; publié par décret impérial sous le ministère de $M$. de Champagny, et rédige par M. F. Péron, naturaliste de l'éxpedition, correspondant de l'Institut de France, de la Sociêté de l'École de Médecine de Paris, des Sociétés philomatique et médicale de la même ville". Paris, 1807-1816.

Phillips, J.A. (2000). Systematics of the Australian species of Dictyopteris (Dictyotales, Phaeophyceae). Australian Systematic Botany 13: 283-324.

Phillips, J.A. and Huisman, J.M. (1997). Dictyopteris serrata (Dictyotales, Phaeophyceae): a poorly known algal species newly recorded from Australia. Botanica Marina 41: 43-49.

Phillips, J.A., King, R.J., Tanaka, J. and Mostaert, A. (1993). Stoechospermum (Dictyotales, Phaeophyceae): a poorly known algal genus newly recorded in Australia. Phycologia 5: 395-398.

Pilbara 21. (1992). A land usage strategy for the Burrup Peninsula. A discussion paper. Western Australian Government, Perth.

Pitt, D.R. and Mills, D.A. (1985). Summary of anemometer data from Conzinc Island: September 1981 to July 1984. Environmental Note 176. Western Australian Department of Conservation and Environment, Perth. $122 \mathrm{pp}$.

Playford, P.E. (1988). Guidebook to the Geology of Rottnest Island. Geological Society of Australia, Western Australian Division, and the Geological Survey of Western Australia. $67 \mathrm{pp}$

Prince, R.I.T. (1986). Dugong in northern waters of Western Australia, 1984. Technical Report 7. Department of Conservation and Land Management, Perth, Western Australia. 38 pp. 
Ryan, G. (1966). Roebourne, Western Australia: Western Australian Geological Survey, 1: 250,000 Geological Series Explanatory Notes.

Sainsbury, K.J., Kailola, P.J. and Leyland, G.G. (1985). Continental shelf fishes of northern and northwestern Australia. 'An illustrated guide. CSIRO, Australia. John Wiley and Sons, London. 375 pp.

Semeniuk, V. (1983). Mangrove distribution in northwestern Australia in relationship to regional and local freshwater seepage. Vegetatio 53: 11-31.

Semeniuk, V. (1986). Terminology for geomorphic units and habitats along the tropical coast of Western Australia. Journal of the Royal Society of Western Australia 68: 53-79.

Semeniuk, V. and Wurm, P.A.S. (1987). The mangroves of the Dampier Archipelago, Western Australia. Journal of the Royal Society of Western Australia 69: 1-87.

Semeniuk, V., Chalmer, P.N. and Le Provost, I. (1982). The marine environments of the Dampier Archipelago. Journal of the Royal Society of Western Australia 65: 97-114.

Semeniuk, V., Kenneally, K.F. and Wilson, P.G. (1978). Mangroves of Western Australia. Handbook 12: 1-92. Western Australian Naturalists Club, Perth.

Simpson, C. (1985a). Environmental factors affecting coral growth in the Dampier Archipelago, Western Australia. Environmental Note 168: 1-14. Western Australian Department of Conservation and Environment, Perth.

Simpson, C. (1985b). Mass spawning of scleractinean corals in the Dampier Archipelago and the implications for management of coral reefs in Western Australia. Bulletin 244: 1-35. Western Australian Department of Conservation and Environment, Perth.

Simpson, C. (1988). Ecology of scleractinian corals in the Dampier Archipelago, Western Australia. Technical Series 23: 1-238. Environmental Protection Authority, Perth, Western Australia.

Simpson, C. and Grey, K.A. (1989). Survey of Crown-ofthorns starfish and coral communities in the Dampier Archipelago, Western Australia. Technical Series 25: 124. Environmental Protection Authority, Perth, Western Australia.

Slack-Smith, R.J. (1967). A report on the Banana prawn nurseries near the Dampier Archipelago. Unpublished report, Department of Fisheries and Fauna, Perth, Western Australia.

Slack-Smith, S. M. (1978a). Marine plants of the rocky shores of the Dampier Archipelago. 27 pp. In Hutchins, J. B., Slack-Smith, S. M. and Marsh, L. M. (eds), Report on the Marine Fauna and Flora of the Dampier Archipelago. Western Australian Museum, Perth. Unpublished reports submitted to Meagher and LeProvost, Consultant Biologists, December 1978.

Slack-Smith, S. M. (1978b). Molluscs of the rocky shores of the Dampier Archipelago. 35 pp. In Hutchins, J. B., Slack-Smith, S. M. and Marsh, L. M. (eds), Report on the Marine Fauna and Flora of the Dampier Archipelago. Western Australian Museum, Perth. Unpublished reports submitted to Meagher and LeProvost, Consultant Biologists, December 1978.

Steedman, R.K. (1985). Air quality meteorology of the Burrup Peninsula, Western Australia June, 1982 to December 1984. Volume 1 text and appendices $A$ to G. R. K.
Steedman Ltd. Report R271 August 1985. Unpublished report to Woodside Offshore Petroleum Ltd..

Studer, T. (1878). Übersicht der steinkorallen aus der familie der Madreporaria aporosa Eupsammia und Turbinaria, welche auf der reise S.M.S. Gazelle um die erde gessamelt wurden. Monatsbericht der Koniglich Preussischen Academie der Wissenschaften zu Berlin 1878: 625-655.

Studer, T. (1880). Übersicht über die während der reise S.M.S. Corvette Gazelle um die erde 1874-76 gesammelten Echinoiden. Monatsbericht der Koniglich Preussischen Academie der Wissenschaften zu Berlin 1880: 861-885.

Studer, T. (1882). Übersicht über die Ophiuriden, welche während der reise S.M.S. 'Gazelle' um die erde 187476 gesammelten wurden. Abhandlungen Preussische Akademie der Wissenschaften 1882: 1-37.

Studer, T. (1884). Verzeichniss der während der reise S.M.S. 'Gazelle' um die erde 1874-76 gesammelten Asteriden und Euryaliden. Abhandlungen Preussische Akademie der Wissenschaften 1884: 1-64.

Taylor, J.D. and Glover, E.A. (2003). Food of the giants: field observations on the diet of Syrinx aruanus (Linnaeus, 1758) (Turbinellidae), the largest living gastropod. In Wells, F.E., Walker, D.I. and Jones, D.S. (eds), Proceedings of the Eleventh International Marine Biological Workshop: The Marine Flora and Fauna of Dampier, Western Australia: 217-223. Western Australian Museum, Perth.

Taylor, J.D. and Glover, E.A. (2004). Diversity and distribution of subtidal benthic molluscs from the Dampier Archipelago, northwestern Australia; results of the 1999 dredge survey (DA2/99). In Jones, D.S. (ed.), Report on the Results of the Western Australian Museum/Woodside Energy Ltd. Partnership to explore the Marine Biodiversity of the Dampier Archipelago, Western Australia 1998-2002. Records of the Western Australian Museum Supplement 66: 247-291.

Taylor, J.D. and Morton, B. (1996). The diets of predatory gastropods in the Cape d'Aguilar Marine Reserve. Asian Marine Biology 13: 141-166.

Thorman, R. (1983). Vegetation map of the Dampier Archipelago prepared for the Western Australian Department of Conservation and Environment, Perth. Unpublished map.

Tuckfield, T. (1955). William Dampier - where did he land? Journal and Proceedings of the Western Australian Historical Society 5: 5-15.

Veron, J.E.N. and Marsh, L.M. (1988). Hermatypic corals of Western Australia: records and annotated species list. Records of the Western Australian Museum, Supplement 29: 1-136.

Veth, P., Bradshaw, E., Gara, T., Hall, N., Haydock, P. and Kendrick, P. (1993). Burrup Peninsula Aboriginal Project. Unpublished Report, Department of Conservation and Land Management, Perth, Western Australia.

Vinnicombe, P. (2002). Petroglyphs of the Dampier Archipelago: background to development and descriptive analysis. Rock Art Research 19: 3-27.

Wells, F.E. and Lalli, C.M. (2003). Aspects of the ecology of the mudwhelks Terebralia palustris and $T$. semistriata 
in northwestern Australia. In Wells, F.E., Walker, D.I. and Jones, D.S. (eds), Proceedings of the Eleventh International Marine Biological Workshop: The Marine Flora and Fauna of Dampier, Western Australia: 193-208. Western Australian Museum, Perth.

Weltner, W. (1897). Verzeichnis der bisher beschriebenen recenten Cirripedien-Arten. Mit Angabe der im Berliner Museum vorhandenen species und ihrer fundorte. Archiv fiir Naturgeschichte 63: 227-280.

Wilson, B.R. (1972). Western Australian coral reefs with preliminary notes on a study at Kendrew Island, Dampier Archipelago. In Report of the Crown of Thorns Seminar, Brisbane, Queensland, August 1972: 47-58. Australian Government Publishing Service, Canberra.

Wilson, B.R. and Marsh, L.M. (1974). Acanthaster studies on a Western Australian coral reef. In Proceedings of the Second International Symposium on Coral Reefs. Great Barrier Reef Committee, Brisbane, Queensland, 1973 1: $621-630$.

Wilson, B.R. and Marsh, L.M. (1975). Seasonal behaviour of a 'normal' population of Acanthaster in Western Australia. In Crown-of-Thorns Starfish Seminar Proceedings, Brisbane, 6 September 1974: 167-179. Australian Government Publishing Service, Canberra.

Wilson, B.R. and Marsh, L.M. (1979). Coral reef communities at the Houtman Abrolhos, Western Australia, in a zone of biogeographic overlap. Proceedings of the International Sympositum on Marine
Biogeography and Evolution in the Southern Hemisphere, Auckland, New Zealand, 1978. New Zealand Department of Scientific and Industrial Research, Information Series No. 137: 259-278.

Wilson, B.R., Marsh, L.M. and Hutchins, J. B. (1974). A puffer fish predator of Crown-of-Thorns in Australia. Search 6: 601-602.

Wilson, B.R. and Stoddart, J. (1988). A thorny problem Crown of Thorns Starfish in WA. Landscope, Spring edition: 35-39.

Woodside Petroleum Development Ltd. (1986). Woodside's guide to fishing on the Dampier Archipelago I. Woodside Offshore Petroleum Ltd., Perth.

Woodside Petroleum Development Ltd. (1989). Woodside's guide to fishing on the Dampier Archipelago. Part II. Woodside Offshore Petroleum Ltd., Perth.

Woodside Petroleum Development Ltd. (1992). Woodside's guide to fishing on the Dampier Archipelago. Part III. Woodside Offshore Petroleum Ltd., Perth.

Woodside Petroleum Development Pty. Ltd. (1979a). North West Shelf Development: Environmental Review and Management Program. Perth. 33 pp.

Woodside Petroleum Development Pty. Ltd. (1979b). Draft Environmental Impact Statement and Environmental Review and Management Programme, North West Shelf Development project. Woodside Petroleum Development Pty. Ltd., Perth, Western Australia. 135 pp. 